\title{
Rh-induced Support Transformation and $R h$ Incorporation in Titanate Structures and Their Influence on Catalytic Activity
}

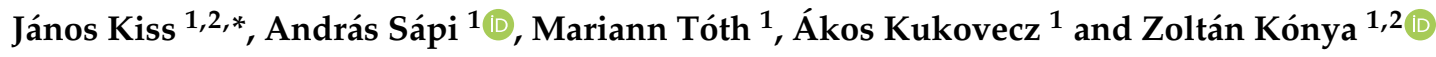 \\ 1 Department of Applied and Environmental Chemistry, University of Szeged, Interdisciplinary Excellence \\ Centre, Rerrich Béla tér 1, H-6720 Szeged, Hungary; sapia@chem.u-szeged.hu (A.S.); \\ tothmaja@gmail.com (M.T.); kakos@chem.u-szeged.hu (Á.K.); konya@chem.u-szeged.hu (Z.K.) \\ 2 MTA-SZTE Reaction Kinetics and Surface Chemistry Research Group, Rerrich Béla tér 1, H-6720 Szeged, \\ Hungary \\ * Correspondence: jkiss@chem.u-szeged.hu
}

Received: 23 December 2019; Accepted: 7 February 2020; Published: 10 February 2020

\begin{abstract}
Rh}$ is one of the most effective metals in several technologically important heterogeneous catalytic reactions, like the hydrogenation of $\mathrm{CO}_{2}$, and $\mathrm{CO}$, the $\mathrm{CO}+\mathrm{H}_{2} \mathrm{O}$ reaction, and methane and ethanol transformations. Titania and titanates are among the most frequently studied supports for Rh nanoparticles. The present study demonstrates that the nature of the support has a marked influence on the specific activity. For comparison, the catalytic activity of $\mathrm{TiO}_{2} \mathrm{P} 25$ is also presented. It is pointed out that a certain amount of $\mathrm{Rh}$ can be stabilized as cation $\left(\mathrm{Rh}^{+}\right)$in ion-exchange positions (i.e., in atomic scale distribution) of the titanate framework. This ionic form does not exists on $\mathrm{TiO}_{2}$. We pay distinguished attention not only to the electronic interaction between $\mathrm{Rh}$ metal and the titania/titanate support, but also to the Rh-induced phase transitions of one-dimensional titanate nanowires (TiONW) and nanotubes (TiONT). Support transformation phenomena can be observed in Rh-loaded titanates. Rh decorated nanowires transform into the $\mathrm{TiO}_{2}(\mathrm{~B})$ phase, whereas their pristine counterparts recrystallize into anatase. The formation of anatase is dominant during the thermal annealing process in both acid-treated and Rh-decorated nanotubes; Rh catalysis this transformation. We demonstrate that the phase transformations and the formation of Rh nanoclusters and incorporated $\mathrm{Rh}$ ions affect the conversion and the selectivity of the reactions. The following initial activity order was found in the $\mathrm{CO}_{2}+\mathrm{H}_{2}, \mathrm{CO}+\mathrm{H}_{2} \mathrm{O}$ and $\mathrm{C}_{2} \mathrm{H}_{5} \mathrm{OH}$ decomposition reactions: $\mathrm{Rh} / \mathrm{TiO}_{2}$ (Degussa $\mathrm{P} 25) \geq \mathrm{Rh} / \mathrm{TiONW}>\mathrm{Rh} / \mathrm{TiONT}$. On the other hand it is remarkable that the hydrogen selectivity in ethanol decomposition was two times higher on $\mathrm{Rh} / \mathrm{TiONW}$ and $\mathrm{Rh} / \mathrm{TiO}(\mathrm{NT})$ catalysts than on $\mathrm{Rh} / \mathrm{TiO}_{2}$ due to the presence of $\mathrm{Rh}^{+}$cations incorporated into the framework of the titanate structures.
\end{abstract}

Keywords: Rh catalyst; titanate nanowires; titanate nanotubes; ion-exchange; phase transformation; $\mathrm{CO}_{2}$ hydrogenation; methanation; water-gas-shift reaction; ethanol decomposition

\section{Introduction}

\subsection{General Surway}

The heterogeneous catalysis remains as a very well focused research field in the 21st century. The search for new, effective catalysts is very important for future energy production, energy storage and also from an environmental point of view [1,2]. $\mathrm{CO}_{2}$ is a problem and there is a need for the chemical activation of such stable molecules. Catalytic $\mathrm{CO}_{2}$ hydrogenation not only reduces the anthropogenic emission of $\mathrm{CO}_{2}$ but also produces value-added liquid fuels and feedstock chemicals. $\mathrm{CO}_{2}$ conversion using $\mathrm{H}_{2}$ produced from the electrolysis of water generated by wind or solar energy 
produces carbon monoxide $(\mathrm{CO})$, methane $\left(\mathrm{CH}_{4}\right)$ and methanol $\left(\mathrm{CH}_{3} \mathrm{OH}\right)$, etc. This approach is considered promising to reduce the atmospheric $\mathrm{CO}_{2}$ level [3-10]. Because of the chemical inertness of $\mathrm{CO}_{2}$ and its thermodynamic stability, the chemical activation of $\mathrm{CO}_{2}$ is a rather popular buzzword in contemporary catalysis and surface science. However, efficient and selective $\mathrm{CO}_{2}$ conversion remains a challenge [11-14]. The water gas shift reaction (WGSR) [15,16], ethanol (methanol) decomposition and ethanol steam reforming (ESR) serve hydrogen for the energy source [17-19].

The hydrogenation of $\mathrm{CO}_{2}$, the WGSR and the ethanol transformation reactions, including ESR, were investigated extensively on Rh-related catalysts because of $\mathrm{Rh}$ was found to be an excellent catalytic material among noble metals. The supports, depending on their nature, significantly influence the catalytic activity of the $\mathrm{Rh}$. $\mathrm{TiO}_{2}$ was the most effective support and the least impressive one was $\mathrm{SiO}_{2}$. For example, in $\mathrm{CO}_{2}$ hydrogenation using $\mathrm{TiO}_{2}$ support, mainly methane was formed with a high conversion and with a high selectivity, in some cases higher than 95\% [20-22]. The catalytic reactions have been investigated as a function of the electric properties of the $\mathrm{TiO}_{2}$ support adjusted by doping $\mathrm{TiO}_{2}$ with lower cations and higher valences $[23,24]$. It was demonstrated that the electric conductivity of $\mathrm{TiO}_{2}$ influences the catalytic properties of $\mathrm{Rh}$.

A broad literature coverage and excellent reviews are available on $\mathrm{TiO}_{2}$ and $\mathrm{TiO}_{2}$ nanostructures [25-27], perovskites [28] and anodically oxidized vertically oriented freestanding $\mathrm{TiO}_{2}$ nanotube arrays [29,30]. The last 15-20 years have seen a steadily increasing number of studies on the properties of polytitanate-based layered nanostructures like titanate nanowires and nanotubes. Various tubular metal oxides have been developed recently and are of interest because they are expected to exhibit novel physical and chemical properties. One-dimensional $\mathrm{TiO}_{2}$-related nanomaterials with a high morphological specificity, such as nanotubes and nanowires, have attracted considerable attention due to their interesting physicochemical properties [31-34]. Kasuga et al. [35] prepared the first titanate nanotubes (TiONT) by hydrothermal synthesis. Later, this method was applied to convert the self-assembled TiONT into nanowires (TiONW) in a revolving autoclave in our laboratory $[36,37]$. These 1D nanostructures are of great interest in catalysis because they have high specific areas and cation exchange capacities, providing a high metal (e.g., $\mathrm{Co}, \mathrm{Cu}, \mathrm{Ni}, \mathrm{Ag}$ and $\mathrm{Au}$ ) dispersion [34,38-41]. Bavykin and Walsh published an excellent review about the preparation, characterization and applications (including catalysis) of titania and titanate nanotubes [42]. A comprehensive review was also published specifically about characterization at the atomic scale and the surface properties of metal-modified TiONT and TiONW [43,44].

Recently, it was discovered that titanate nanostructures are able to stabilize $\mathrm{Au}$ at a high dispersion [45-51]. To date, several important reactions have been discovered to be catalyzed by titanate-supported gold. It was found that gold-containing TiONT has a higher activity than Degussa P-25 in the photo-oxidation of acetaldehyde [47], in the photo-induced degradation of formic acid [48], in the low-temperature WGS reaction [49] and in carbon monoxide oxidation [46,50,51]. They are also active catalysts of thermally induced $\mathrm{CO}_{2}$ hydrogenation [52]. Very recently, it was revealed that gold nanoparticles supported on titanate nanowires are efficient in the UV photo-induced reaction of methane (with and without water) $[13,53]$ and in $\mathrm{CO}_{2}$ hydrogenation [14]. Additional examples confirmed that other noble metals supported on titanate nanostructures also perform remarkably in certain catalytic processes. Deposited $\mathrm{Pt}, \mathrm{Pd}, \mathrm{Ru}$, and $\mathrm{Au}$ on the surface of titanate nanotubes were prepared for catalytic purposes [54]. Titania and titanate nanostructures and their chemically doped and cocatalyst decorated derivatives have been extensively studied in degrading organic impurities being present water as well as on solid surfaces. While the electrons accumulated typically on the co-catalyst nanoparticles $(\mathrm{Pt}, \mathrm{Pd}, \mathrm{Rh})$ are expected to interact with unsaturated and aromatic bonds in organic moieties, the holes on the surface of $\mathrm{TiO}_{2}$ are responsible for the initiation of oxidative processes that may result in $\mathrm{C}-\mathrm{C}$ bond scission, dehydrogenation and the like [55-62]. Recently, platinum catalysts supported on layered protonated titanate-derived titania nanoarrays were found to have a high activity in $\mathrm{CO}$ and $\mathrm{NO}$ oxidation as compared to Pt catalysts through wet-impregnation on the anatase $\mathrm{TiO}_{2}[63]$. 
As Rh on titania-based supports exhibits excellent catalytic activity in many reactions, we intended to test the $\mathrm{Rh} /$ titanates in some technologically important reactions. Before testing, it is desirable to summarize the Rh-titanate interactions and review the chemical environment of Rh on titanate nanostructures as these parameters play an important role in heterogeneous catalysis. We should first provide a literature survey on Rh-induced transformations of titanates (wires and tubes) and the surface characterization of Rh on titanate supports, including the formation of Rh nanoparticles on the surface and the incorporation of $\mathrm{Rh}^{+}$ions into the titanate frameworks.

\subsection{Literature Review of Phase Transformation of Heat-Treated Pristine (H-Titanate) and Rh-Decorated Titanates}

Titanate nanowires (TiONW) and nanotubes (TiONT) were prepared by hydrothermal conversion of anatase $\mathrm{TiO}_{2}$ as described previously [35,36,53]. After preparation, acid washing was applied in order to replace as much $\mathrm{Na}^{+}$ions in the framework of protons as possible. The resulting material is generally called "H-form" titanate.

A characteristic difference between the behavior of titanate nanotubes and nanowires is that in heat-treated nanotubes, the $E_{2 g}$ mode is found at exactly the anatase position $\left(636 \mathrm{~cm}^{-1}\right)$ from $573 \mathrm{~K}$ onwards, whereas in nanowires, this mode experiences a gradual red shift from $648 \mathrm{~cm}^{-1}$ at $573 \mathrm{~K}$ to $636 \mathrm{~cm}^{-1}$ at $873 \mathrm{~K}$ [64-66]. A similar effect was observed by Du et al. [67,68] and Scepanovic et al. [68,69] in their temperature-dependent in situ Raman studies of nanocrystalline anatase.

In the case of Rh-loaded titanates, we concluded from Raman spectra that (i) the heat treatment of Rh-loaded titanate nanostructures yield different phase structure from $673 \mathrm{~K}$, (ii) Rh loaded TiONT transforms into anatase, and (iii) the Rh loaded $\mathrm{TiONW}$ exhibits the $\mathrm{TiO}_{2}$ (B) structure [69,70].

From the study of $\mathrm{XRD}$, it was concluded that the structure of Rh-free (pristine) TiONW is a mixture of different titanate forms, mostly with $\mathrm{TiO}_{2}(\mathrm{~B})$ and $\mathrm{H}_{\mathrm{x}} \mathrm{Na}_{(2-\mathrm{x})}$ components (Figure 1A).The transformation is continuous during the thermal annealing. Around $473 \mathrm{~K}$ and $573 \mathrm{~K}$, the layered structure collapses and the anatase phase shows up with a low crystallinity. At a higher temperature, the formation of the anatase phase becomes dominant as the electron diffraction patterns show in Figure 1A, together with the appearance of the characteristic anatase reflections (101), (004), (200), (105), (211) and (204) at $25.3^{\circ}, 37.8^{\circ}, 48.1^{\circ}, 53.9^{\circ}, 55.1^{\circ}$ and $62.4^{\circ}$.

A
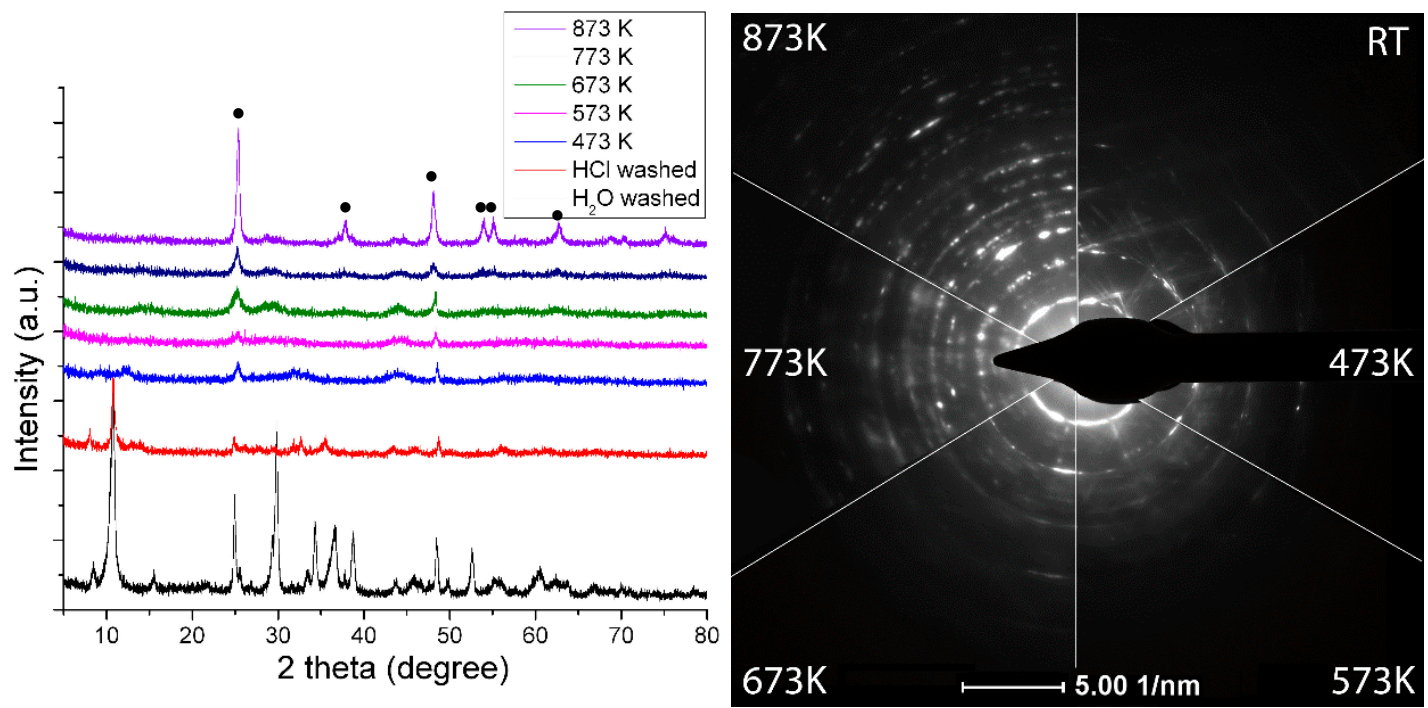

Figure 1. Cont. 
B

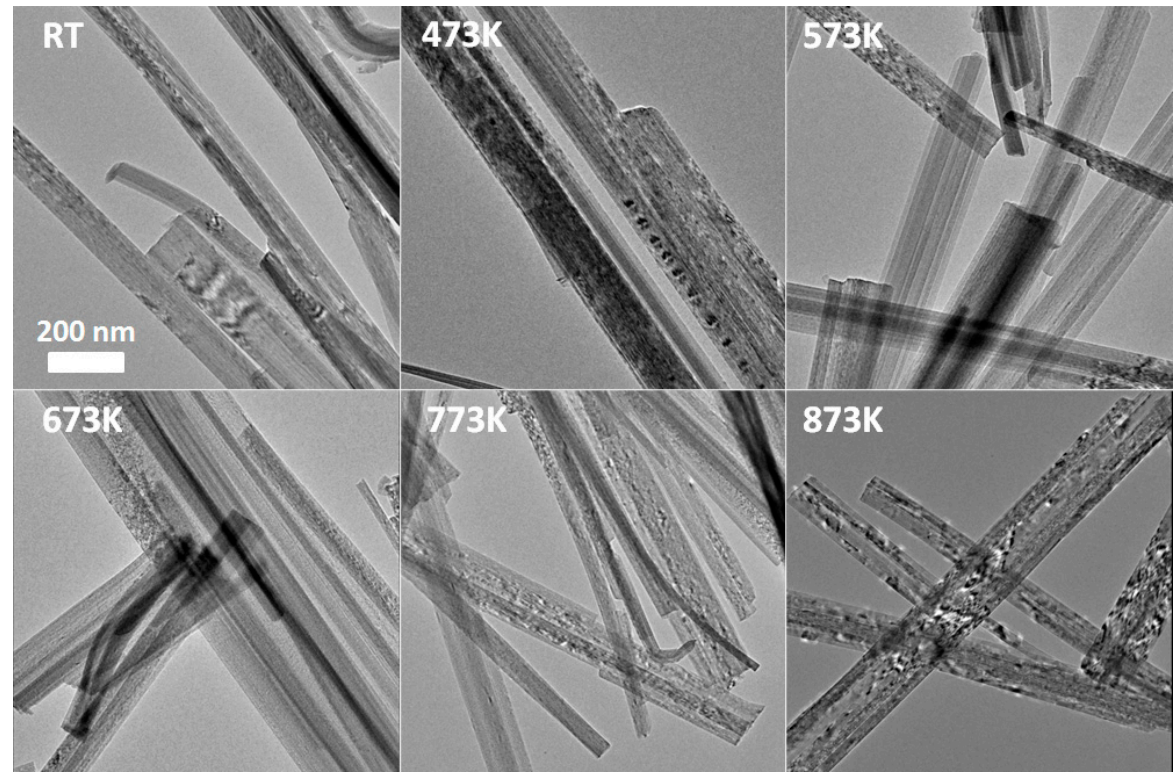

Figure 1. (A) XRD of TiONW treated at different temperatures. The bottom graph displays the XRD profile of $\mathrm{H}_{2} \mathrm{O}$ washed TiONW. $\bullet$ denotes anatase reflection (B) TEM images of TiONW treated at different temperatures. Reproduced from [70].

The TiONW preserves the wire-like morphology during the heating up to $873 \mathrm{~K}$. The holey structure is due to the continuous transformation of $\mathrm{TiONW}$ to $\mathrm{TiO}_{2}$ (anatase) followed by water desorption from the structure (Figure 1B).

XRD shows that acidic treatment resulted in a degradation of the initial structure of nanotubes (Figure 2A), which demonstrates the disappearance of the reflection belonging to the tubular interlayer distance $\left(2 \Theta=\sim 10^{\circ}\right)$. The protonation also catalyzes the transformation of the TiONT to the anatase phase [70]. There is no significant effect on the structure below $673 \mathrm{~K}$; however, at a higher temperature, the anatase formation became dominant, as evidenced by the appearance of the anatase reflections (Figure 2A). At higher temperatures, the increased intensity and lower half-width indicate the improvement of anatase crystallinity, as indicated by the electron diffraction patterns in Figure 2A.

The electronmicroscopic pictures (TEM) in Figure 2B demonstrate the tubular morphology of the as-synthesized TiONT with a diameter of $\sim 7 \mathrm{~nm}$ and a length up to $80 \mathrm{~nm}$. In correlation with the XRD results, there is no morphological degradation after heat treatment up to $573 \mathrm{~K}$. The tubular structure collapses and transforms into rod-like nanostructures at a higher temperature. Around $873 \mathrm{~K}$, the tubular morphology is totally collapsed, short nanorods and $\mathrm{TiO}_{2}$ nanoparticles appear with an average size of $\sim 10 \mathrm{~nm}$.

The phase transformation during heat treatment accompanied by structural water loss was investigated and discussed previous studies [31,36,37,42,43,70]. The origin of $\mathrm{H}_{2} \mathrm{O}$ evolution is the adsorbed or lattice water and the surface reaction between hydroxyl groups and hydrogen during the recrystallization process $[43,70]$. These processes could significantly increase the number of defects in TiONW and TiONT and this can catalyze the phase transformation of titanates. Heat treatment induces a reduction of $\mathrm{Ti}^{4+}$ in titanates to $\mathrm{Ti}^{3+}$ and $\mathrm{Ti}^{2+}$, but their detection in the surface layers is not always successful due to the fast oxygen transport from bulk to surface. The reduction extent of these cations with the annealing temperature was monitored by treating nanotube samples in situ in inert atmosphere at different temperatures [43]. When the sample was annealed, the population of reduced $\mathrm{Ti}^{3+}$ atoms increased, giving a $\mathrm{Ti}^{3+} / \mathrm{Ti}^{4+}$ surface atomic ratio of 0.046 and 0.06 at 573 and $773 \mathrm{~K}$, respectively (Table 1). 
A
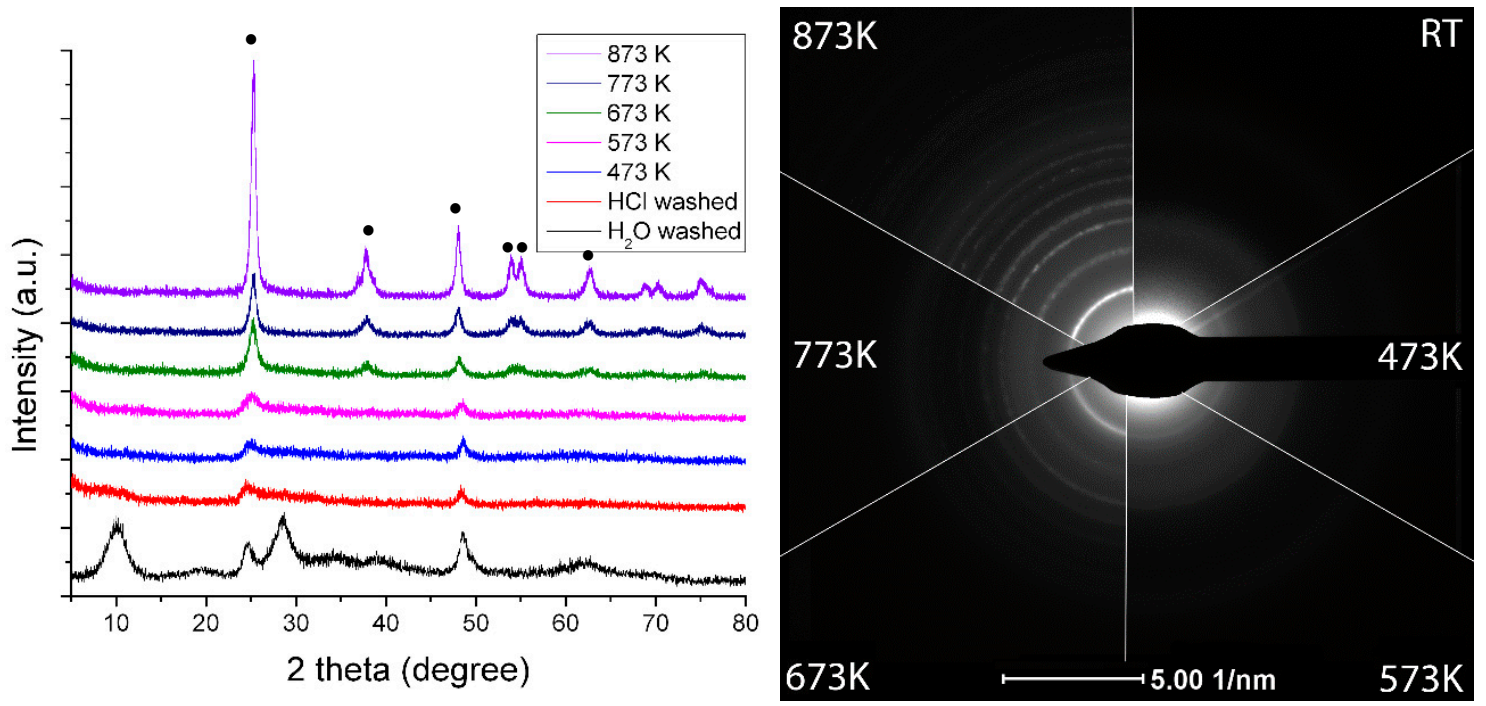

B

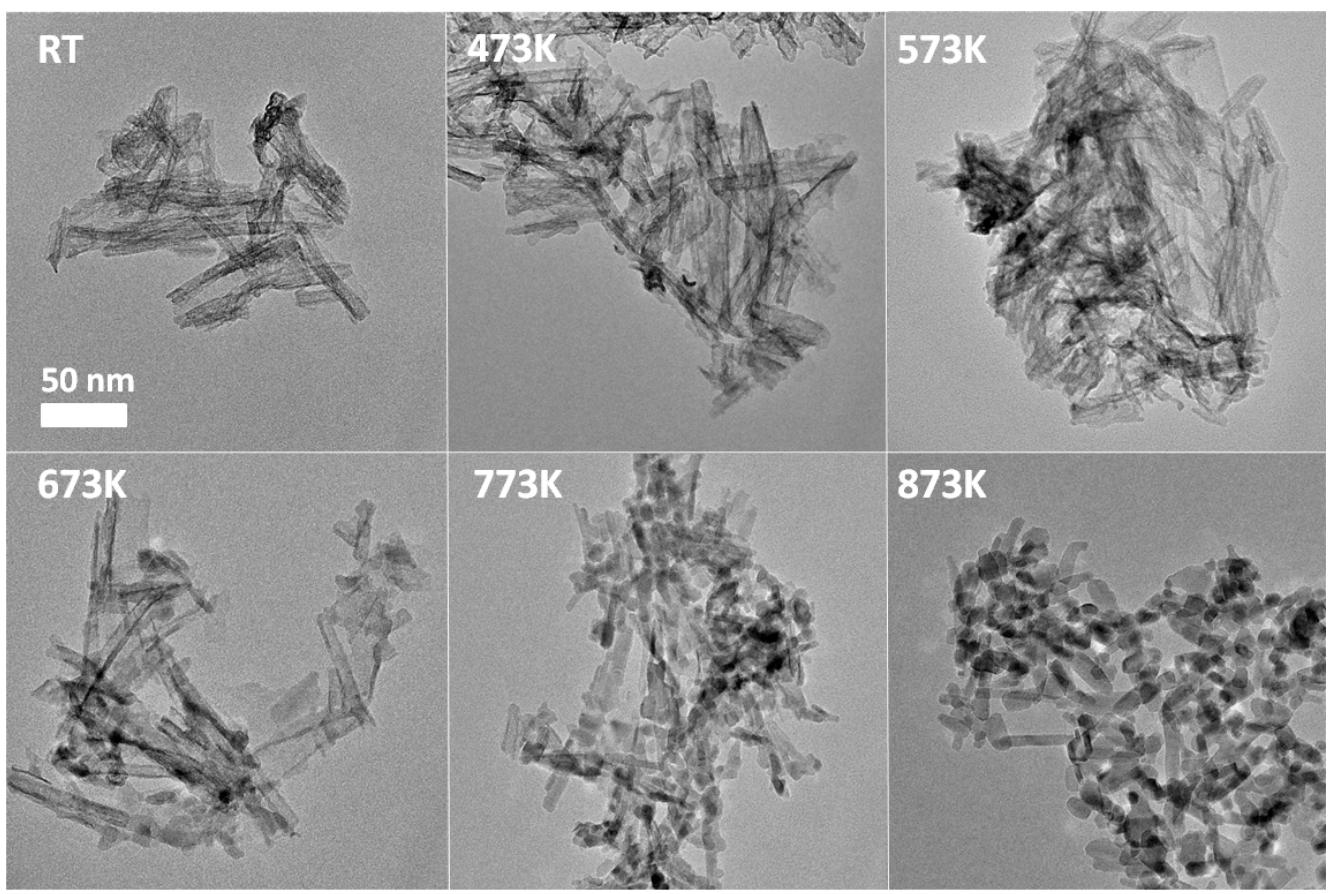

Figure 2. (A) XRD of "H-form" TiONT as a function of temperature. The bottom curve shows the XRD profile of $\mathrm{H}_{2} \mathrm{O}$ washed TiONT. $\bullet$ denotes anatase reflection. (B) TEM images of TiONT treated at different temperatures. Reproduced from Ref. [70]. 
Table 1. XPS parameters of Ti $2 \mathrm{p}_{3 / 2}$ and $\mathrm{O} 1$ s derived from spectral fitting. Reproduced from [43].

\begin{tabular}{|c|c|c|c|c|c|}
\hline $\begin{array}{l}\text { Annealing } \\
\text { Temperature } \\
\left({ }^{\circ} \mathrm{C}\right)\end{array}$ & Assignment & $\begin{array}{c}\text { Binding } \\
\text { Energy }(e V)\end{array}$ & FWHM $^{\text {a }}(\mathrm{eV})$ & $\begin{array}{c}\text { Surface } \\
\text { Atomic Ratio } \\
\mathrm{Ti}^{3+} / \mathrm{Ti}^{4+}\end{array}$ & $\begin{array}{c}\text { Surface } \\
\text { Atomic Ratio } \\
\text { O/Ti }\end{array}$ \\
\hline \multirow{3}{*}{110} & $\mathrm{O} 1 \mathrm{~s}$ & 530.8 & 1.3 & \multirow{3}{*}{0.026} & \multirow{3}{*}{2.48} \\
\hline & $\mathrm{Ti}^{3+} 2 \mathrm{p}_{3 / 2}$ & 457.5 & 1.2 & & \\
\hline & $\mathrm{Ti}^{4+} 2 \mathrm{p}_{3 / 2}$ & 459.1 & 1.2 & & \\
\hline \multirow{3}{*}{200} & $\mathrm{O} 1 \mathrm{~s}$ & 530.8 & 1.2 & \multirow{3}{*}{0.048} & \multirow{3}{*}{2.17} \\
\hline & $\mathrm{Ti}^{3+} 2 \mathrm{p}_{3 / 2}$ & 457.8 & 1.2 & & \\
\hline & $\mathrm{Ti}^{4+} 2 \mathrm{p}_{3 / 2}$ & 459.2 & 1.1 & & \\
\hline \multirow{3}{*}{300} & $\mathrm{O} 1 \mathrm{~s}$ & 530.8 & 1.2 & \multirow{3}{*}{0.046} & \multirow{3}{*}{1.96} \\
\hline & $\mathrm{Ti}^{3+} 2 \mathrm{p}_{3 / 2}$ & 458.1 & 1.4 & & \\
\hline & $\mathrm{Ti}^{4+} 2 \mathrm{p}_{3 / 2}$ & 459.4 & 1.1 & & \\
\hline \multirow{3}{*}{400} & $\mathrm{O} 1 \mathrm{~s}$ & 530.9 & 1.2 & \multirow{3}{*}{0.045} & \multirow{3}{*}{1.89} \\
\hline & $\mathrm{Ti}^{3+} 2 \mathrm{p}_{3 / 2}$ & 458.1 & 1.4 & & \\
\hline & $\mathrm{Ti}^{4+} 2 \mathrm{p}_{3 / 2}$ & 459.4 & 1.1 & & \\
\hline \multirow{3}{*}{500} & $\mathrm{O} 1 \mathrm{~s}$ & 530.8 & 1.2 & \multirow{3}{*}{0.060} & \multirow{3}{*}{1.97} \\
\hline & $\mathrm{Ti}^{3+} 2 \mathrm{p}_{3 / 2}$ & 458.1 & 1.6 & & \\
\hline & $\mathrm{Ti}^{4+} 2 \mathrm{p}_{3 / 2}$ & 459.4 & 1.1 & & \\
\hline
\end{tabular}

${ }^{a}$ Full width at half maximum.

$\mathrm{Rh} / \mathrm{TiONW}$ transform into the $\mathrm{TiO}_{2}(\mathrm{~B})$ structure concluded from XRD measurements as opposed to the rhodium-free counterparts' recrystallization to anatase [70]. The dominant reflections attributed to anatase $25.3^{\circ}(101)$ and $\mathrm{TiO}_{2}$ (B) $24.9^{\circ}$ (110) in the case of $\mathrm{Rh}$-decorated titanate nanowires with a degree of crystallinity of up to $673 \mathrm{~K}$. The lower FWHM values at higher temperatures indicates the fusion of nanoparticles. In the case of Rh-decorated nanotubes (Rh/TiONT), the anatase phase is dominated; reflections are at (101), (004), (200), (105), (211) and (204) at 25.3 $, 37.8^{\circ}, 48.1^{\circ}, 53.9^{\circ}, 55.1^{\circ}$ and $62.4^{\circ}$, respectively [70].

TEM images of Rh-decorated nanowires (Figure 3A) and nanotubes (Figure 3B) thermally treated at $673 \mathrm{~K}$ show the presence of homogeneously dispersed nanoparticles on the surface of the titanate nanostructures [70]. The average nanoparticle diameter is $4.9 \pm 1.4 \mathrm{~nm}$ and $2.8 \pm 0.7 \mathrm{~nm}$ in the case of nanowires and nanotubes, respectively, as shown in the corresponding size distributions. The difference in average diameter and distribution broadening can be explained by the differences in the crystal transformation process, as discussed above. Moreover, the surface diffusion and coalescence kinetics of Rh nanoparticles can also be different on tubular and wire-like titanate nanostructures. 
A

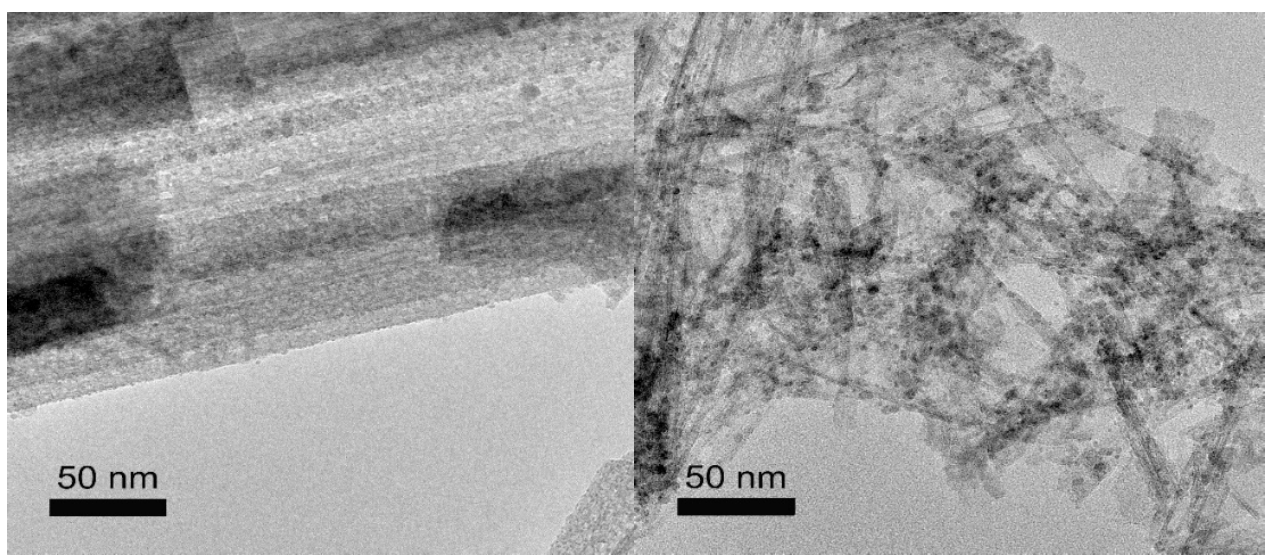

B
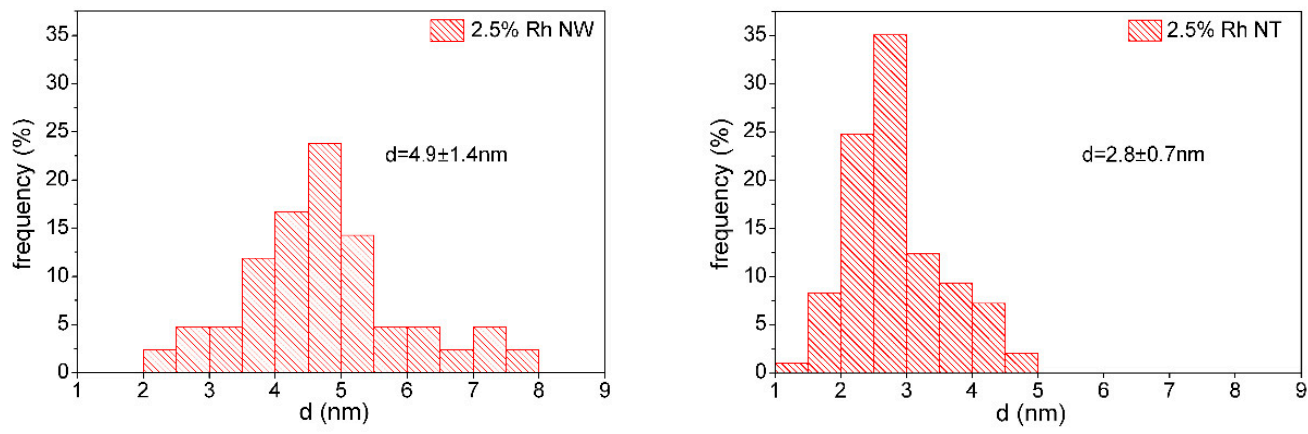

Figure 3. Typical TEM images of $2.5 \% \mathrm{Rh}$ decorated titanate nanowires (A) and titanate nanotubes (B) thermally annealed at $673 \mathrm{~K}$ and the corresponding size distribution of Rh nanoparticles. Reproduced from [70].

It is important to mention that the original size distribution was maintained even at relatively high temperatures (reduction temperature of the catalysts: 473-573 K) on both nanowires and nanotubes. Rh clusters of controlled size can be prepared by physical vapor deposition (PVD) [71-73] and using Rh organometallic precursors [74,75] on $\mathrm{TiO}_{2}(110)$ as well. However, STM [71,76], XPS and LEIS [67] experiments revealed that depending on the original cluster size and the evaporation temperature, the agglomeration of Rh nanoparticles can be significant even below $500 \mathrm{~K}$ on that surface. Therefore, the relatively small cluster sizes obtained on titanate nanowires and nanotubes may indicate that metal diffusion on these nano objects is limited compared to that on well ordered titania.

\subsection{Summary Results on the Morphology and Chemical State of Rh Nanoparticles on Titanates}

The morphology of Rh supported on titanate nanowires and nanotubes was investigated by FTIR spectroscopy employing adsorbed $\mathrm{CO}$ as a probe molecule sensitive to the local surface structure. Adsorbed $\mathrm{CO}$ exhibits at least three different stretching frequencies belonging to certain adsorption sites of Rh on oxide supports [77-82]. The band at $2070-2030 \mathrm{~cm}^{-1}$ is due to CO adsorbed linearly to $\mathrm{Rh}^{0}$ (depending on the coverage), the band at $\sim 1855 \mathrm{~cm}^{-1}$ represents bridge-bonded $\mathrm{CO}\left(\mathrm{Rh}_{2}-\mathrm{CO}\right)$ and the features at $\sim 2100 \mathrm{~cm}^{-1}$ and at $\sim 2020 \mathrm{~cm}^{-1}$ correspond to the symmetric and asymmetric stretching of $\mathrm{Rh}+(\mathrm{CO})_{2}$ (twin CO), respectively. These latter IR signals were detected when the crystallite size was very small $[77,81]$.

On nanowires, the twin form was dominant $\left(2027\right.$ and $\left.2097 \mathrm{~cm}^{-1}\right)$, the signal corresponding to the linear form between the twin peaks was much smaller and the bridge form was hardly observable (Figure 4A). On nanotubes, the linearly adsorbed CO features showed up at $2075 \mathrm{~cm}^{-1}$ between the peaks at 2100 and $2036 \mathrm{~cm}^{-1}$ (twin form) (Figure 4B). From these IR studies, we may conclude that a 
significant part of Rh exists in small cluster sizes (1-3 nm), probably with the $\mathrm{Rh}^{+}$oxidation state on both nanowires and tubes in harmony with the XPS results.

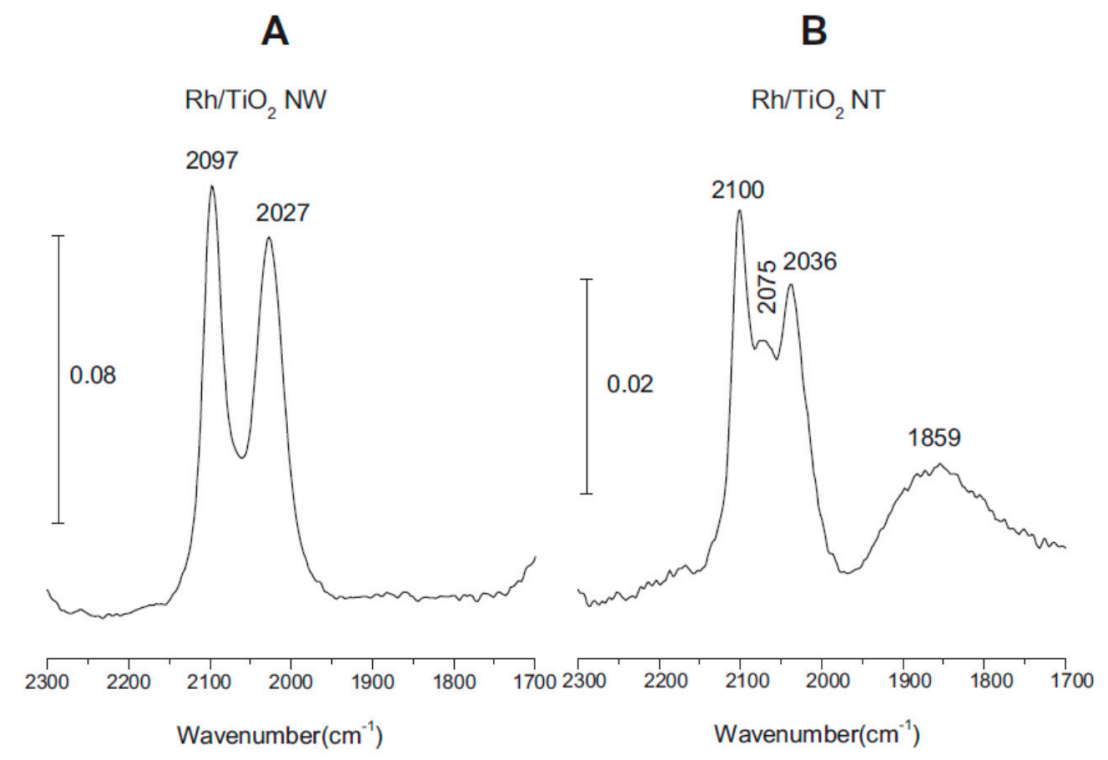

Figure 4. Infrared spectra of adsorbed CO at $300 \mathrm{~K}$; (A) 1\% Rh/TiONW, (B) 1\% Rh/TiONT.

Figure 5 reveals the binding energies of Rh $3 \mathrm{~d}$ orbitals in titanate nanowires and nanotubes. The photoemission from the $\mathrm{Rh} 3 \mathrm{~d}$ peak centered at $309.3 \mathrm{eV}$ at $1 \%$ Rh content and $308.3 \mathrm{eV}$ at $2 \%$ metal content clearly suggests the existence of an oxidation state or a different morphology from the bulk, as the metallic Rh photoemission for $\mathrm{Rh} 3 \mathrm{~d}_{5 / 2}$ is at $307.1 \mathrm{eV}$ [70]. The XP spectra of $\mathrm{Rh} 3 \mathrm{~d}$ for $2 \% \mathrm{Rh}$ content are presented in Figure 5. The nearly $2 \mathrm{eV}$ shift relative to metallic Rh can be attributed to the width of the nanoparticle distribution. The binding energy is affected by the relaxation energy and this so-called "final-state" effect depends on the particle size [83]. A higher binding energy in XPS may correspond to very small metal particles and $\mathrm{Rh}$ ion $\left(\mathrm{Rh}^{+}\right)$stabilized in the framework of wires and tubes. It is strongly suggested that the higher binding energy peak corresponds mainly to Rh ion formed in ion-exchange process.

The stabilization of Rh ion and clusters in small size in titanates and their influence on the phase transformation of both titanate formations can be explained by the increased electronic interaction between Rh and titanate structures. A very similar strong electronic interaction was observed in several cases between reduced titania $\left(\mathrm{TiO}_{2}\right)$ and metals, including $\mathrm{Rh}$ [84-86], except ion-exchange possibility. Due to the preparation methods of titanate nanostructures and the mild reduction of Rh/titanates, the nanowires and nanotubes may contain significantly more defects than commercially used reduced titania. The presence of a high number of defects and oxygen vacancies in titanate could initiate an increased electron flow between metal and titanates. On the other hand, ion exchange between protonated titanates and rhodium occurs, forming positively charged Rh, similarly to silver, cobalt and gold on titanates [34,40,41].

In the following section of the review, the focus is on the effect of the structural differences of the titania-based catalyst support as well as the oxidation state and chemical environment of the active metal $(\mathrm{Rh})$ on the industrially and environmentally important catalytic reactions, such as $\mathrm{CO}_{2}$ hydrogenation, $\mathrm{CO}+\mathrm{H}_{2} \mathrm{O}$ reaction, and $\mathrm{C}_{2} \mathrm{H}_{5} \mathrm{OH}$ decomposition. Nanostructured titanates are characterized by a relatively high specific surface area. The high specific surface area of the support facilitates the high dispersion of the catalyst, while the open mesoporous make the efficient transport of both reagents and products possible [42,43]. In addition to the high surface areas, the titanates contain huge number of defects which also play a significant role in the catalytic reaction. Protonated nanowires and nanotubes have good ionic exchange properties. The incorporation of the ionic form of 
the metal precursor $\left(\mathrm{Rh}^{+}\right)$to the structure can significantly help to increase the loading of the catalysts and maintain a high catalyst dispersion during the reactions, as was nicely presented in the case of platinum supported on layered protonated titanate nanowires [63]. The metal cations resulted in a strong interaction between metal and titanate support, leading the enhanced thermal and chemical stability of the catalyst.

A
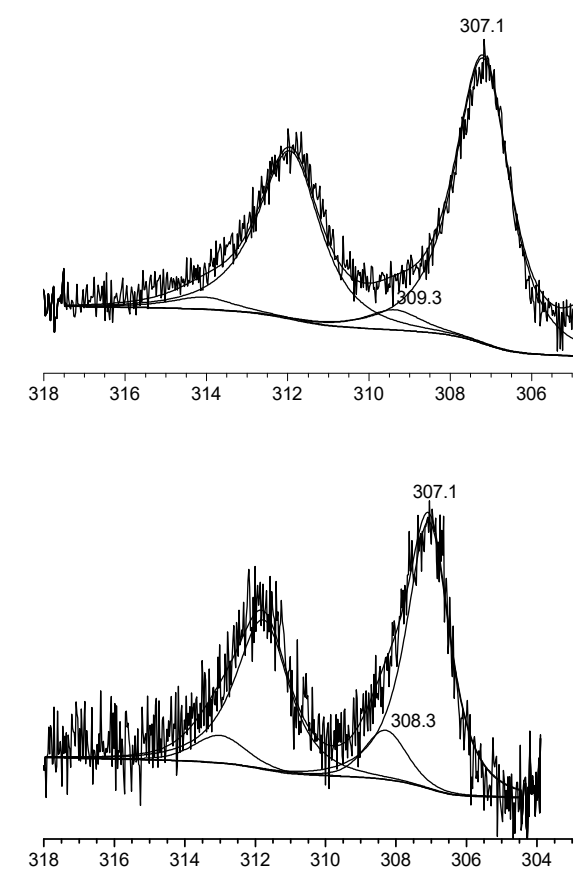

B
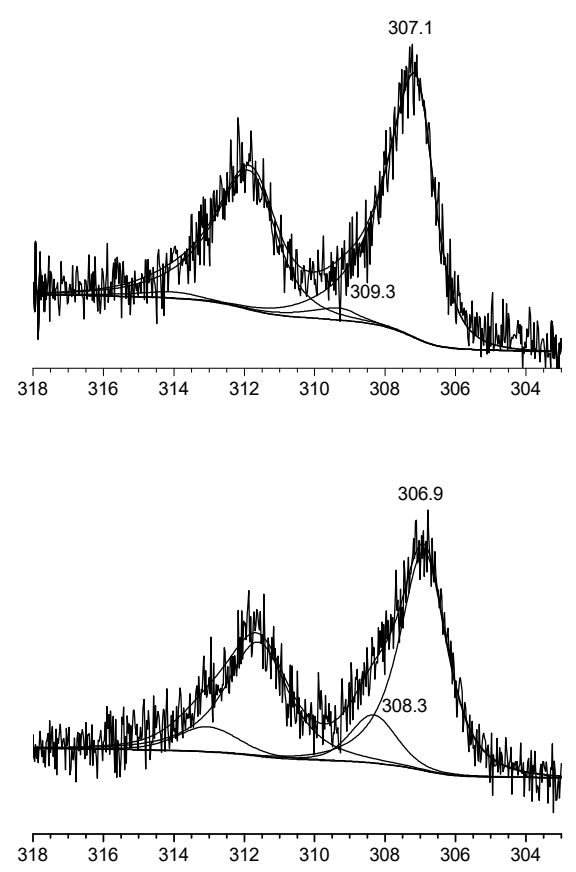

Binding energy [eV]

Figure 5. XP spectra of $\mathrm{Rh} 3 \mathrm{~d}$ on titanate nanowire (A) and nanotube (B) with $1 \% \mathrm{Rh}$ content (upper spectra) and $2 \%$ metal content (lower spectra). Reproduced from [70].

We demonstrate the effect of Rh-induced phase transformation in titanates and the influence of $\mathrm{Rh}$ nanoparticles and single $\mathrm{Rh}^{+}$ion stabilized in ion-exchange positions on the conversion and selectivity of the studied reactions. The ion-exchange possibility allows an atomic-scale distribution of metal cations in the titanate lattice. A suitable choice of the ionic form of the metal precursor can help significantly in increasing catalyst loading and maintaining a high catalyst dispersion. The ionic form of metals may increase the catalytic activity in cases where the redox mechanism is important. In some cases, we investigated the effect of co-adsorbed gold atom on the catalytic activity of $\mathrm{Rh} /$ titanates catalysts to study the special metal or ionic Rh and gold interactions.

\section{Materials and Methods}

Titanate nanowires (TiONW) and nanotubes (TiONT) were prepared by hydrothermal conversion of anatase $\mathrm{TiO}_{2}$, as described previously [35,36,53]. After acid washing of titanates, most Na ion was replaced with hydrogen in this way and "H-form" titanate was obtained.

The prepared titanates can be characterized briefly; the outer diameter of the titanate nanotubes is 7-10 nm and their length is 50-170 nm, and they are composed of 4-6 wall layers. The diameter of their inner channel is typically $5 \mathrm{~nm}[35,43,53]$. Titanate nanowires are the thermodynamically most stable form of sodium trititanate. Their diameter is $45-110 \mathrm{~nm}$ and their length is between 1.8 and $5 \mu \mathrm{m}[36,43]$. The specific surface area of titanate nanotubes is rather large $\left(\sim 185 \mathrm{~m}^{2} \mathrm{~g}^{-1}\right)$ due to their 
readily accessible inner channel surface, whereas that of titanate nanowires is $\sim 20 \mathrm{~m}^{2} \mathrm{~g}^{-1}$. The BET surface area of Degussa $\mathrm{TiO}_{2} \mathrm{P} 25$ applied here was $50 \mathrm{~m}^{2} \mathrm{~g}^{-1}$.

$\mathrm{Rh} /$ titanate nanocomposites were prepared by the impregnation method using $\mathrm{RhCl}_{3} \times 3 \mathrm{H}_{2} \mathrm{O}$ (Johnson Matthey) solutions to yield 1 and $2.5 \mathrm{wt} \%$ metal content. [33,43,87-90]. The samples were dried in air; finally, the catalysts were reduced in hydrogen atmosphere at $573 \mathrm{~K}$ for 1 hour. The characterization of the pristine and Rh-decorated titanates were made by XPS, HTEM, XRD and Raman spectrometry described in detail previously [43,70]. Bimetallic Au-Rh/titanates were prepared the same way [88-90]. Au, Rh and their coadsorbed layers with different composition were obtained by impregnation of the supports with the mixtures of calculated volumes of $\mathrm{HAuCl}_{4}$ (Fluka) and $\mathrm{RhCl}_{3} \times 3$ $\mathrm{H}_{2} \mathrm{O}$ (Johnson Matthey) solution to yield $1 \mathrm{wt} \%$ metal content.

For IR measurements, a Genesis (Mattson) spectrometer was applied. A BioRad FTS-135 FT-IR spectrometer supplied with a diffuse reflectance attachment was used for DRIFTS. The DRIFTS measurements were performed in an ultra-high vacuum system described previously $[13,52,90]$. The samples were pressed onto a Ta mesh. The mesh was placed at the bottom of a UHV sample manipulator. In total, 256 scans were registered at a spectral resolution of $2 \mathrm{~cm}^{-1}$. A Whatman purge gas generator was used to purge the optical path.

The catalytic set up was described in more detail previously $[20,52,89,90]$. The reactions were carried out in a fixed bed continuous-flow reactor. The amount of catalyst used was usually about $0.1 \mathrm{~g}$. The dead volume of the reactor was filled with quartz chips. The flow rate was usually $50 \mathrm{~mL} / \mathrm{min}$. Analysis of the product gases was performed with a Chrompack 9001 and Agilent 7890 gas chromatograph using Porapak QS columns. The products were detected simultaneously by TC and FI detectors with the help of a methanizer. The impregnated powders were dried in air at $383 \mathrm{~K}$ for $3 \mathrm{~h}$. The final pre-treatment was at 573-600 K in hydrogen atmosphere. The $\mathrm{CO}_{2}+\mathrm{H}_{2}$ reaction was studied at $493 \mathrm{~K}$ and $30,000 \mathrm{~h}^{-1} \mathrm{~mL} \mathrm{~g}^{-1}$ space velocity to achieve a relatively low conversion. The WGS reaction was carried out at $550 \mathrm{~K}$ while the ethanol decomposition was followed at $600 \mathrm{~K}$. The amount and the activity of surface carbon formed in the catalytic reactions during $80 \mathrm{~min}$ were determined by temperature-programmed reduction (TPR). The catalyst was heated at a linear rate of $15 \mathrm{~K} / \mathrm{min}$ hydrogen as carrier gas.

\section{Effect of Titania Structure and Form of the Rh Metal on Heterogeneous Catalytic Reactions}

\section{1. $\mathrm{CO}_{2}$ Hydrogenation on Titania and Titanate Supported $\mathrm{Rh}$}

The hydrogenation of $\mathrm{CO}_{2}$ was studied extensively on titania $\left(\mathrm{TiO}_{2}\right)$ supported $\mathrm{Rh}$ [20-24,91-93] and the reaction was also investigated on titanate (TiONW and TiONT)-supported Rh recently $[62,90,94]$. In all cases, the supported Rh showed an excellent catalytic activity. The catalytic activities obtained on $\mathrm{Rh} / \mathrm{TiO}_{2}, \mathrm{Rh} / \mathrm{TiONW}$ and $\mathrm{Rh} / \mathrm{TiONT}$ are summarized in Table 2 and the effects of co-deposited $\mathrm{Au}$ are also displayed and compared with the results obtained on $\mathrm{Au} / \mathrm{TiO}_{2}, \mathrm{Au} / \mathrm{TiONW}$ and $\mathrm{Au} / \mathrm{TiONT}$. The catalysts were pretreated by reduction with hydrogen at $573 \mathrm{~K}$. At this temperature, the nanotube structure converted partially to anatase, while the Rh induced phase transformation from wire-like structure to $\mathrm{TiO}_{2}$ (B) phase also happened to an extent. In the case of $\mathrm{Rh} / \mathrm{TiONT}$, we mixed tube-like and nanoanatase composition, in the case $\mathrm{Rh} / \mathrm{TiONW}$, wire-like and $\mathrm{TiO}_{2}(\mathrm{~B})$ structure co-exist. We note here that Degussa $\mathrm{TiO}_{2} \mathrm{P} 25$ has a mainly rutile structure. The main reaction product was $\mathrm{CH}_{4}$ in all cases and minor $\mathrm{CO}$ formation was observed only on Rh/TiONT. Only traces of $\mathrm{C}_{2}$ hydrocarbons were detected at $493 \mathrm{~K}$. The methane conversions obtained at $493 \mathrm{~K}$ are displayed in Figure 6. H-form titanates were used always in the $\mathrm{CO}_{2}$ hydrogenation experiments. 
Table 2. Characteristic data for hydrogenation of carbon dioxide over $\mathrm{Rh}, \mathrm{Au}, \mathrm{Au}-\mathrm{Rh}$ bimetallic clusters supported on titanate nanotubes, nanowires and $\mathrm{TiO}_{2}$. The reaction temperature was $493 \mathrm{~K}$.

\begin{tabular}{|c|c|c|c|c|c|c|c|c|}
\hline \multirow[t]{2}{*}{ Catalyst } & \multirow{2}{*}{$\begin{array}{c}\text { Amount of } \\
\text { Adsorbed } \mathrm{H}_{2} \\
\mu \mathrm{mol} / \mathrm{g}\end{array}$} & \multicolumn{2}{|c|}{$\begin{array}{c}\text { Conversion } \\
\%\end{array}$} & \multicolumn{2}{|c|}{$\begin{array}{c}\mathrm{CH}_{4} \text { Formation Rate } \\
\mu \mathrm{mol} / \mathrm{gs}\end{array}$} & \multirow{2}{*}{$\begin{array}{c}\begin{array}{c}\text { Turnover } \\
\text { Number } \\
\mathrm{s}^{-1} \times 10^{-3}\end{array} \\
\text { in } 80 \mathrm{~min}\end{array}$} & \multirow{2}{*}{$\begin{array}{c}\begin{array}{c}E_{\mathrm{a}} \\
\mathrm{kJ} / \mathrm{mol}\end{array} \\
\text { in } 80 \\
\mathrm{~min}\end{array}$} & \multirow[t]{2}{*}{$\begin{aligned} \Sigma \mathrm{C} \\
\mu \mathrm{mol} / \mathrm{g}\end{aligned}$} \\
\hline & & in $5 \mathrm{~min}$ & $\begin{array}{l}\text { in } 80 \\
\text { min }\end{array}$ & in $5 \mathrm{~min}$ & $\begin{array}{l}\text { in } 80 \\
\min \end{array}$ & & & \\
\hline $\mathrm{Rh} / \mathrm{TiO}_{2}$ & 7.9 & 6.9 & 6.7 & 4.9 & 4.4 & 278 & 98.3 & 78.8 \\
\hline $\mathrm{Rh} / \mathrm{TiONW}$ & 7.5 & 8.9 & 4.5 & 6.6 & 3.2 & 213 & 96.5 & 121.5 \\
\hline $\mathrm{Rh} / \mathrm{TiONT}$ & 4.1 & 1.4 & 1 & 0.8 & 0.5 & 61 & 88.4 & 132.0 \\
\hline $\mathrm{Au}-\mathrm{Rh} / \mathrm{TiO}_{2}$ & 2.4 & 3.3 & 2.5 & 2.2 & 1.5 & 312 & 81.3 & 38.9 \\
\hline $\mathrm{Au}-\mathrm{Rh} / \mathrm{TiONW}$ & 5.0 & 1.5 & 1.3 & 1.1 & 0.9 & 90 & 85.3 & 98.6 \\
\hline $\mathrm{Au}-\mathrm{Rh} / \mathrm{TiONT}$ & 2.5 & 0.4 & 0.4 & 0.2 & 0.1 & 20 & 98.8 & 215.7 \\
\hline $\mathrm{Au} / \mathrm{TiO}_{2}$ & 0 & 0.0006 & 0.0002 & $\begin{array}{l}3.7 \times \\
10^{-4}\end{array}$ & $1 \times 10^{-4}$ & - & - & 17.2 \\
\hline $\mathrm{Au} / \mathrm{TiONW}$ & 0 & 0.005 & 0.09 & $\begin{array}{l}3.5 \times \\
10^{-3}\end{array}$ & $6 \times 10^{-4}$ & - & - & - \\
\hline $\mathrm{Au} / \mathrm{TiONT}$ & 0 & 036 & 0.098 & $\begin{array}{l}8.3 \times \\
10^{-4}\end{array}$ & $\begin{array}{l}2.1 \times \\
10^{-4}\end{array}$ & - & - & 3.0 \\
\hline
\end{tabular}

$\mathrm{E}_{\mathrm{a}}$ Activation energy for $\mathrm{CH}_{4}$ formation. $\Sigma \mathrm{C}$ Amount of surface carbon formed in the reaction at $493 \mathrm{~K}$ during 80 minutes.

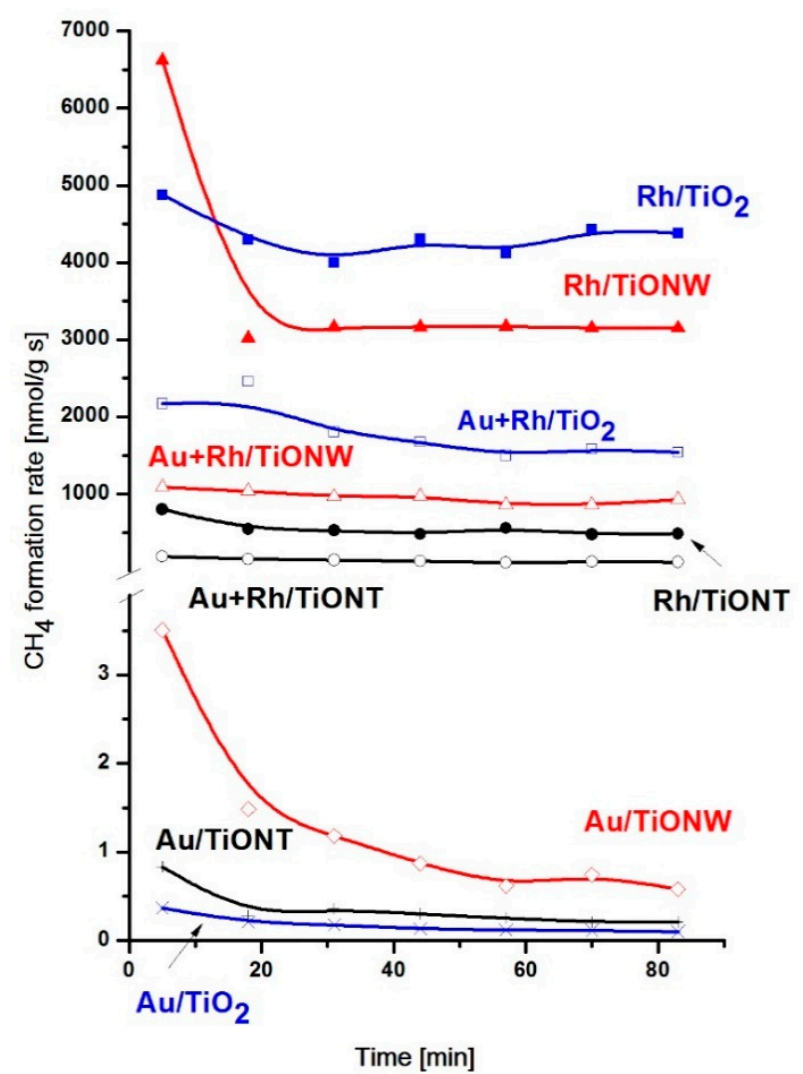

Figure 6. Rate of methane formation over $\mathrm{Rh} / \mathrm{TiO}_{2}, \mathrm{Rh} / \mathrm{TiONW}, \mathrm{Rh} / \mathrm{TiONT}, \mathrm{Au}-\mathrm{Rh} / \mathrm{TiO}_{2}, \mathrm{Au}-\mathrm{Rh} / \mathrm{TiONW}$, $\mathrm{Au}-\mathrm{Rh} / \mathrm{TiONT}, \mathrm{Au} / \mathrm{TiO}_{2}, \mathrm{Au} / \mathrm{TiONW}, \mathrm{Au} / \mathrm{TiONT}$ catalysts at $493 \mathrm{~K}$.

The activity order of the supported Rh samples in the first minutes of the reaction decreased in the order $\mathrm{Rh} / \mathrm{TiONW}>\mathrm{Rh} / \mathrm{TiO}_{2}>\mathrm{Rh} / \mathrm{TiONT}$. The conversion of $\mathrm{CO}_{2}$ on $\mathrm{Rh} / \mathrm{TiONW}$ decreased significantly in time, whereas in the other cases the $\mathrm{CO}_{2}$ consumption was relatively steady. $\mathrm{Rh} / \mathrm{TiO} 2$ displayed a somewhat higher steady state activity. The differences in activity cannot be explained by different surface areas. We should consider several other factors. No doubt that the different titanate phases had a decisive role. It seems that the mixed tube-like nanostructured anatase composition of 
nanotubes does not prefer the methanation of $\mathrm{CO}_{2}$. There is a significant difference in the number of the available active sites evidenced by the $\mathrm{H}_{2}$ dispersion measurements. This can be attributed to the deactivation of Rh-based active sites that resulted from the structural transformation of the nanotubes due to their thermal instability. On the other hand, the ratio of the number of active Rh nanocluster and $\mathrm{Rh}^{+}$could be hardly determined, but we suppose that the positively charged Rh successfully helped the activation of $\mathrm{CO}_{2}$ and the further reaction of intermediates (see below). It is remarkable that there is higher tendency of carbon deposition on titanates comparing to $\mathrm{TiO}_{2} \mathrm{P} 25$, which could better inhibit the reaction. The amount of deposited carbon decreased in the order of TiONT $>$ TiONW $>\mathrm{TiO}_{2}$, with the exception of supported Au samples.

A drastic decrease in conversion was experienced when the Au-Rh bimetallic samples were used as catalysts but the activity order of the samples remained the same. We should note that the supported $\mathrm{Au}$ samples has a very poor activity in $\mathrm{CO}_{2}$ hydrogenation. When we discuss the catalytic behavior of bimetallic catalysts, we should consider that the Au-Rh interaction on titanates ( $\mathrm{Au}-\mathrm{Rh} / \mathrm{TiONW}$ ) produces a core-shell structure similar to the well defined $\mathrm{TiO}_{2}(110)$. In previous works, it was demonstrated with STM, XPS and LEIS measurements that Rh core-Au shell clusters can be formed on $\mathrm{TiO}_{2}(110)$ if $\mathrm{Au}$ is post deposited by physical vapor deposition (PVD) on the substrate containing $\mathrm{Rh}$ clusters [91-93,95-97]. The surface composition of Au-Rh clusters on titanate nanocomposite was also investigated by LEIS [89]. As Figure 7 demonstrates, the Rh LEIS intensity decreased dramatically with the increasing gold content. The most intriguing feature was observed in the $0.5 \% \mathrm{Au}+0.5 \% \mathrm{Rh}$ case. In monometallic systems, gold and rhodium $\mathrm{He}^{+}$scattering signals appeared at 753 and $707 \mathrm{eV}$, respectively. On bimetallic nanocomposite, however, only the gold signal showed up (Figure 7).

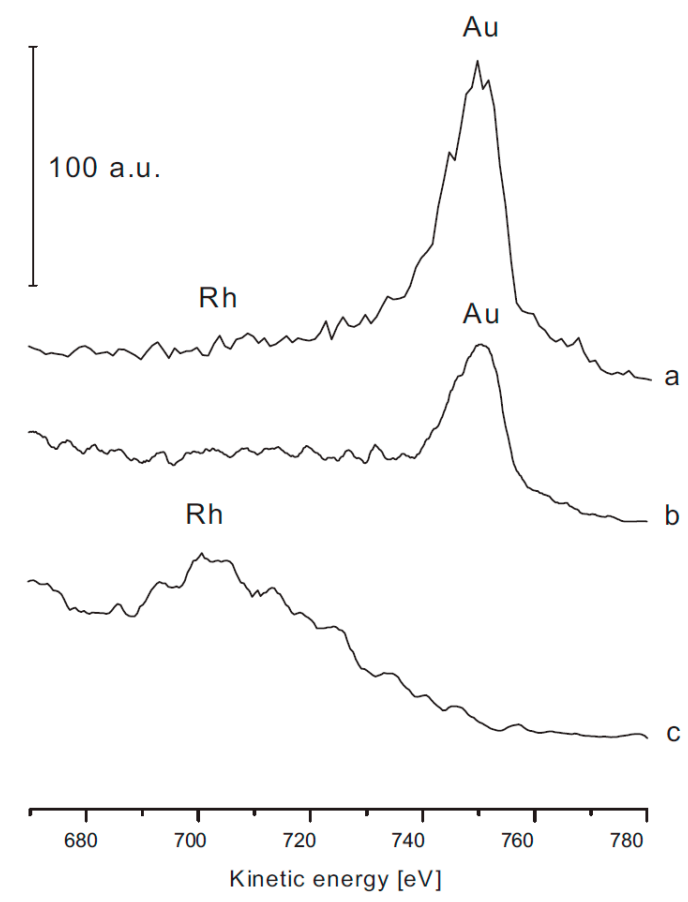

Figure 7. Low-energy ion scattering spectra (LEIS) of $1 \% \mathrm{Au} / \mathrm{TiONW}$ (b), $1 \% \mathrm{Rh} / \mathrm{TiONW}$ (c), $0.5 \% \mathrm{Au}+$ $0.5 \% \mathrm{Rh} / \mathrm{TiONW}$ (a). Reproduced from [89].

If the Au completely and uniformly covers the Rh clusters (core-shell structure), it is plausible that adsorbed CO cannot occur (CO does not adsorb on Au surface at $300 \mathrm{~K}$ ). Yet, strong CO bands appeared at $300 \mathrm{~K}$ at a pressure of $1.3 \mathrm{mbar}$. The peaks correspond to the linear form at $2070 \mathrm{~cm}^{-1}$ and the twin CO mode at 2098 and $2033 \mathrm{~cm}^{-1}$ (Figure 8B). 
A

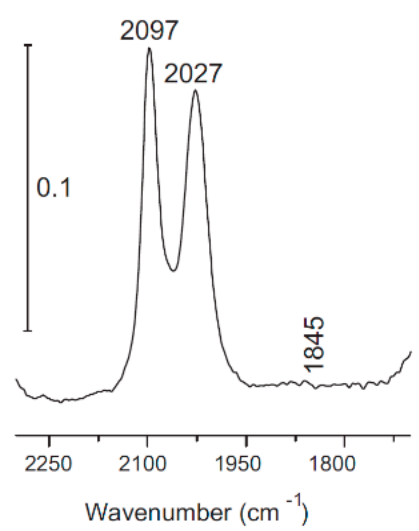

B

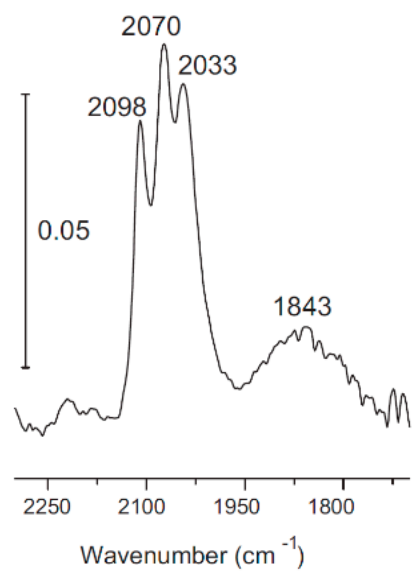

Figure 8. FTIR spectra of adsorbed CO at $300 \mathrm{~K}:$ (A) $1 \% \mathrm{Rh} / \mathrm{TiONW}$ and (B) $0.5 \% \mathrm{Au}+0.5 \% \mathrm{Rh} / \mathrm{TiONW}$. Reproduced from [89].

Apparently, there is a contradiction between the results of LEIS and CO adsorption infrared experiments. There are no Rh atoms in the topmost layer (Figure 7), but adsorbed $\mathrm{CO}$ was detected by FTIR on this surface (Figure 8). This discrepancy can be explained by a CO-induced surface reconstruction. The adsorption of $\mathrm{CO}$ on $\mathrm{Au}-\mathrm{Rh}$ clusters may promote the diffusion of $\mathrm{Rh}$ to the surface of the cluster. Similar phenomena were observed recently in other bimetallic systems on $\mathrm{TiO}_{2}(110)[98,99]$. The adsorption of $\mathrm{CO}$ on bimetallic clusters can induce the diffusion of $\mathrm{Rh}$ to the surface from the core-shell structure. The CO may destroy the core-shell. Another possibility is that there is a continuous thermal fluctuation of $\mathrm{Rh}$ and $\mathrm{Au}$ atoms within the bimetallic clusters, and for short periods, Rh atoms can appear on the cluster surface on which the $\mathrm{CO}$ adsorption may occur $[100,101]$. In the case of $\mathrm{CO}_{2}$ methanation on $\mathrm{Au}-\mathrm{Rh} / \mathrm{TiONW}$, the activity loss can be explained by the distortion of the core-shell structure by reactants, as was discussed in the case of $\mathrm{CO}$ interaction. In any case, further studies are needed to understand the reactants-induced restructuring of $\mathrm{Rh}-\mathrm{Au}$ clusters in detail.

The activation energy of $\mathrm{CO}_{2}$ hydrogenation was calculated from the temperature dependence of the $\mathrm{CH}_{4}$ formation rate at the steady state. The obtained $81-98 \mathrm{~kJ} / \mathrm{mol}$ value is in a good agreement with previous results obtained for this Rh catalysized reaction [20]. It is important to note that the activation energies calculated on monometallic or bimetallic (Au-Rh) samples were almost identical (Table 2).

The infrared spectra registered in the DRIFT cell during $\mathrm{CO}_{2}$ hydrogenation showed that on $\mathrm{Rh} / \mathrm{TiONW}$ (Figure 9) and Rh/TiONT (Figure 10), an absorption band was present in the CO region from the beginning of the reaction at 2045 and $2049 \mathrm{~cm}^{-1}$, respectively. The intensities and the positions of these bands did not change significantly during the catalytic reaction. On $\mathrm{Rh} / \mathrm{TiONW}$, absorptions at 1775-1765, 1628, 1557-1555, and $1379 \mathrm{~cm}^{-1}$ were found (Figure 9). On Rh/TiONT, a shoulder was also observed at about $1960 \mathrm{~cm}^{-1}$ and bands were detected at 1767, $1640 \mathrm{~cm}^{-1}$ and $1568 \mathrm{~cm}^{-1}$ (Figure 10). Similar spectral features were found when $\mathrm{Au}-\mathrm{Rh} / \mathrm{TiONW}$ and $\mathrm{Au}-\mathrm{Rh} / \mathrm{TiONT}$ were used as catalysts, but the intensities of the $\mathrm{CO}$ bands and the band at $1770 \mathrm{~cm}^{-1}$ were weaker. On $\mathrm{Rh} / \mathrm{TiO}_{2}$, an intensive absorption was detected at $2049 \mathrm{~cm}^{-1}$ and weak bands were observable at 1620 and $1570 \mathrm{~cm}^{-1}$. There was no peak at $\sim 1767 \mathrm{~cm}^{-1}$. 
A

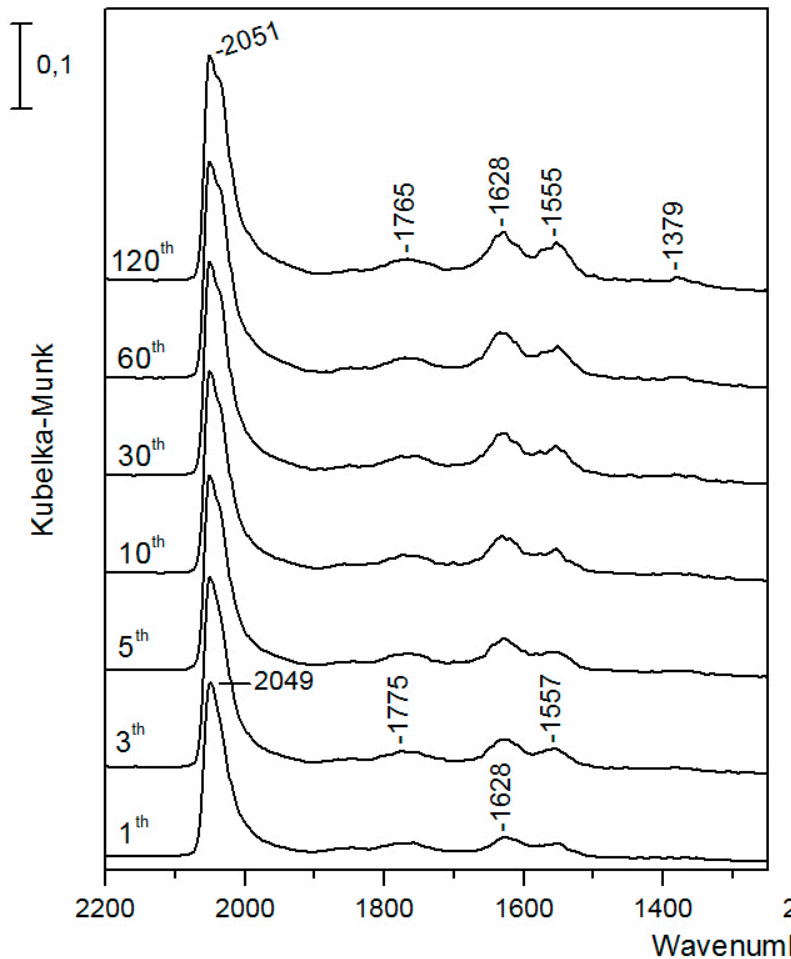

B

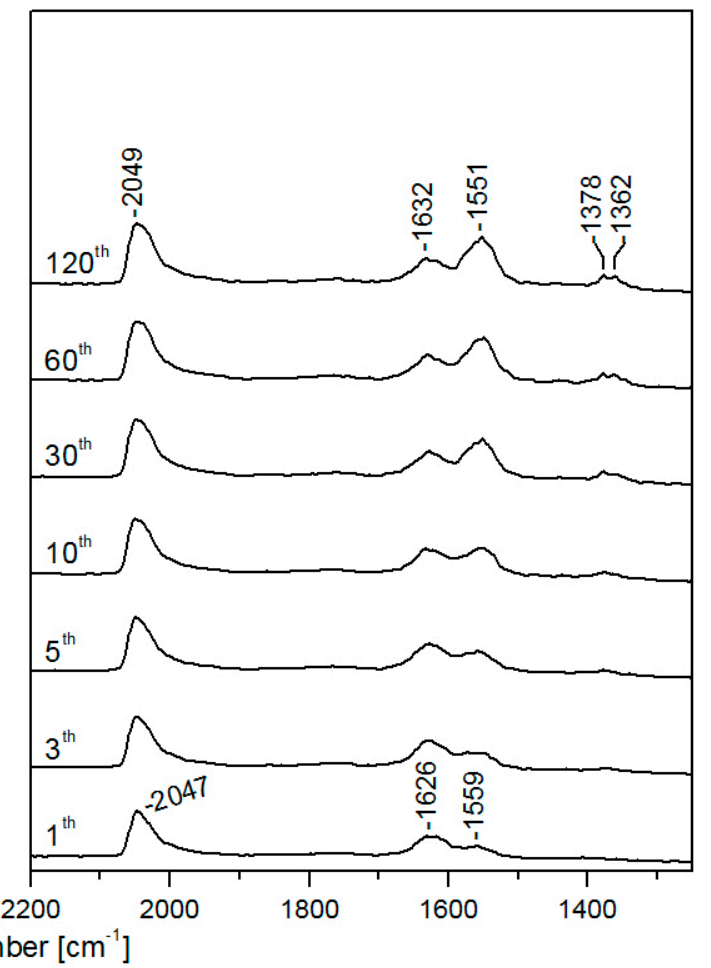

Figure 9. Infrared spectra registered during $\mathrm{CO}_{2}+\mathrm{H}_{2}$ reaction at $493 \mathrm{~K}$ on Rh/TiONW (A) and $\mathrm{Au}-\mathrm{Rh} / \mathrm{TiONW}$ (B). The spectral labels indicate the time (in minutes) passed since the beginning of the reaction.

A

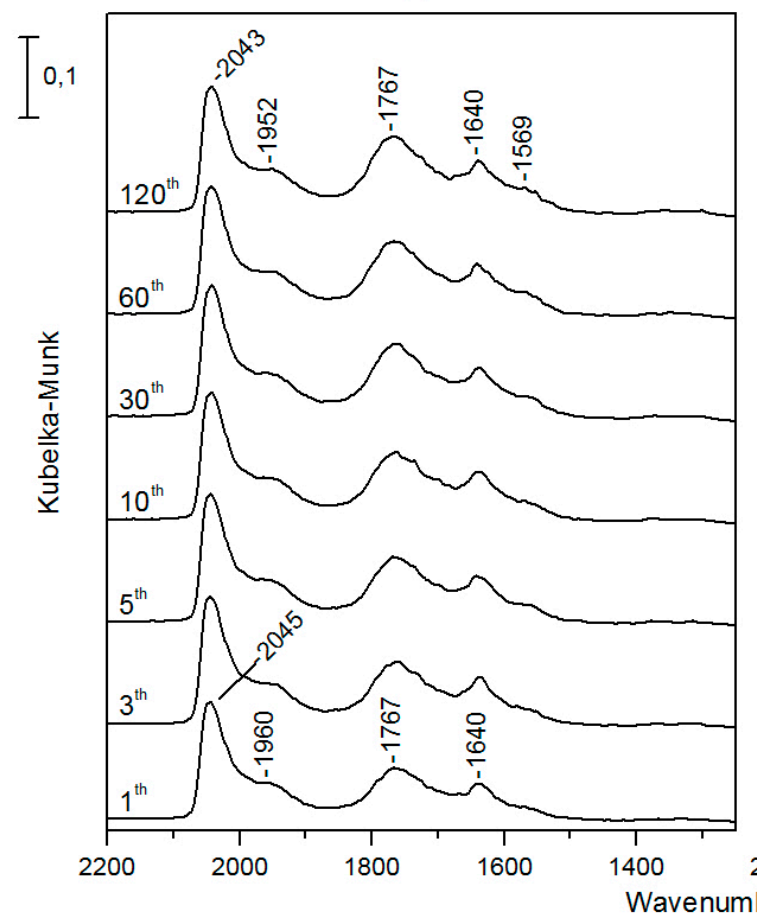

B

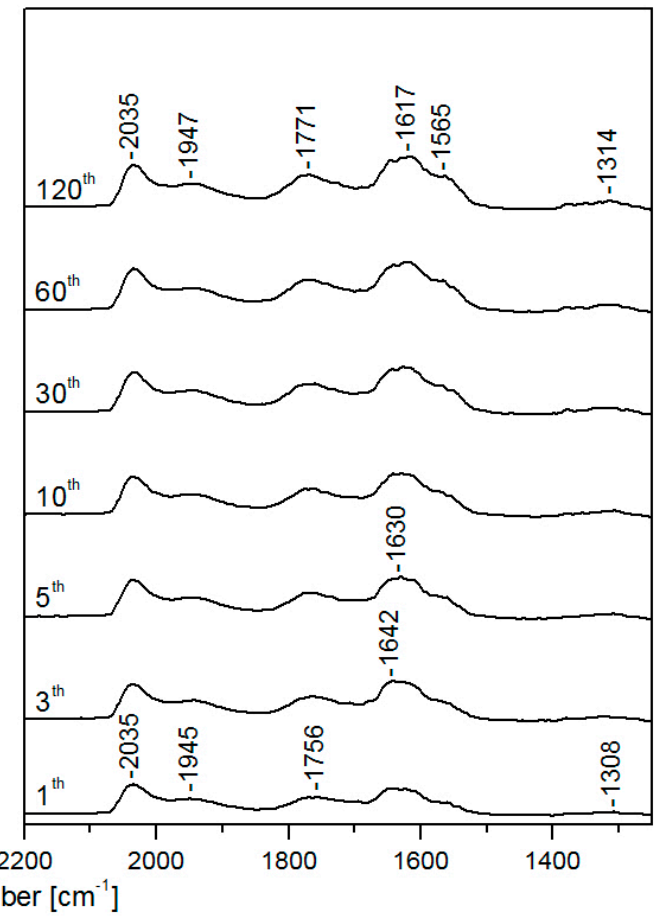

Figure 10. Infrared spectra registered during the $\mathrm{CO}_{2}+\mathrm{H}_{2}$ reaction at $493 \mathrm{~K}$ on Rh/TiONT (A) and $\mathrm{Au}-\mathrm{Rh} / \mathrm{TiONT}$ (B). Spectral labels indicate the time (in minutes) passed since the beginning of the reaction. 
The bands detected between $1550-1570 \mathrm{~cm}^{-1}$ and $1379 \mathrm{~cm}^{-1}$ could be assigned to the asymmetric and symmetric vibration of the OCO group of formate species, respectively [94,102-107]. The absorption found at about $1620 \mathrm{~cm}^{-1}$ could be attributed to water formed in the reaction. The other bands below $1700 \mathrm{~cm}^{-1}$ are due to different carbonates bonded to the supports [108].

The assignation of the band at $\sim 1760 \mathrm{~cm}^{-1}$, detected only on nanostructured titanate support is more complicated. This band was not observed on titania-supported Rh catalysts [20,91]. We could assign this band tentatively to formaldehyde of formic acid. However, the absorption band of the $\mathrm{C}=\mathrm{O}$ group of formaldehyde adsorbed on $\mathrm{Rh} / \mathrm{TiO}_{2}$ appears at lower wavenumbers, at about $1727 \mathrm{~cm}^{-1}$, and it forms at higher temperatures [109]. Although the vibration frequency of $\mathrm{C}=\mathrm{O}$ groups in gaseous $\mathrm{HCOOH}$ is $1770 \mathrm{~cm}^{-1}$ [110], our investigated feature cannot be assigned to this band because it remained observable even when the samples were flushed with He after the catalytic reaction. Low-frequency CO vibration (under $1790 \mathrm{~cm}^{-1}$ ) has been observed in $\mathrm{CO}$ adsorption on $\mathrm{Mn}$, $\mathrm{La}, \mathrm{Ce}, \mathrm{Fe}$ promoted $\mathrm{Rh} / \mathrm{SiO}_{2}$ catalysts [111-113]. The same feature appeared on Pt/zeolites during $\mathrm{CO}_{2}$ hydrogenation [114]. It was suggested that Lewis acid sites caused the downward shift of the $\mathrm{CO}$ ligand vibration through the interaction between the Lewis acid and the oxygen atom of $\mathrm{CO}$. The carbon atom of chemisorbed $\mathrm{CO}$ bonded to a Rh atom and its oxygen tilted to a metal ion. We are inclined to assign the investigated band at about $1770 \mathrm{~cm}^{-1}$ to such tilted $\mathrm{CO}$ bonds to the $\mathrm{Rh}$ and interaction with an oxygen vacancy $\left(\mathrm{Ti}^{3+}\right)$ of the titanate support. When $\mathrm{Rh}$ was partially covered by gold, the intensity of this band decreased (Figures 9 and 10). The tilted CO configuration is illustrated in Figure 11.

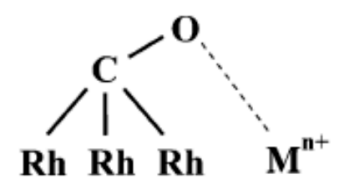

Figure 11. Schematic illustration of the tilted CO configuration on $\mathrm{Rh} /$ titanate catalysts. $\mathrm{M}^{\mathrm{n}+}$ represents a $\mathrm{Ti}^{3+}$ site.

Taking into account the surface intermediates formed during the reaction (adsorbed $\mathrm{CO}$ and formate) and the reaction products (mainly methane and, to a lesser extent, $\mathrm{CO}$ ), we propose that the hydrogenation of $\mathrm{CO}_{2}$ proceeds via the reversed water gas shift reaction mechanism $[115,116]$ and via $\mathrm{Rh}^{+}$and hydrogen assisted C-O cleavage in $\mathrm{CO}$ or $\mathrm{H}_{\mathrm{n}} \mathrm{CO}[20,93,107,113]$.

The $\mathrm{CO}_{2}$ activation (formation of anionic radical) may proceed more easily on defect sites and on $\mathrm{Rh}^{+}$located in the ion-exchange position on titanates, and then it reacts with the adsorbed hydrogen atom:

$$
\begin{aligned}
\mathrm{CO}_{2(\mathrm{a})^{-*}}+2 \mathrm{H}_{(\mathrm{a})} & \rightarrow \mathrm{H}_{\mathrm{n}} \mathrm{CO}_{(\mathrm{a})}+\mathrm{OH}_{(\mathrm{a})} \\
\mathrm{H}_{\mathrm{n}} \mathrm{CO}_{(\mathrm{a})}+\mathrm{H}_{(\mathrm{a})} & \rightarrow \mathrm{CH}_{\mathrm{x}}+\mathrm{OH}_{(\mathrm{a})} \\
\mathrm{CH}_{3(\mathrm{a})}+\mathrm{H}_{(\mathrm{a})} & \rightarrow \mathrm{CH}_{4(\mathrm{~g})}
\end{aligned}
$$

In parallel, a realistic CO formation route could be the decomposition of bidentate formate [101,103]:

$$
\mathrm{HCOO}_{(\mathrm{a})} \rightarrow \mathrm{CO}_{(\mathrm{a})}+\mathrm{OH}_{(\mathrm{a})} \rightarrow \mathrm{CO}_{(\mathrm{g})}+\mathrm{H}_{2} \mathrm{O}_{(\mathrm{g})}
$$

On the other hand, formate bonded close to the metal-oxide interface decomposes forming $\mathrm{CH}_{4}[104,106]$. The metallic Rh could deliver a sufficient amount of hot hydrogen atoms to rapture the $\mathrm{C}-\mathrm{O}$ bond in formate species, the reaction of formate might be also catalyzed by positively charged $\mathrm{Rh}$ ion in titanate framework:

$$
\begin{gathered}
\mathrm{HCOO}_{(\mathrm{a})}+2 \mathrm{H}_{(\mathrm{a})} \rightarrow \mathrm{H}_{2} \mathrm{COH}_{(\mathrm{a})} \rightarrow \mathrm{H}_{2} \mathrm{C}_{(\mathrm{a})}+\mathrm{OH}_{(\mathrm{a})} \\
\mathrm{H}_{2} \mathrm{C}_{(\mathrm{a})}+2 \mathrm{H}_{(\mathrm{a})} \rightarrow \mathrm{CH}_{4(\mathrm{~g})}
\end{gathered}
$$


Coke formation detected after reaction can be ascribed to the subsequent dehydrogenation of $\mathrm{CH}_{2(\mathrm{a})}$.

In the $\mathrm{Na}-\mathrm{Rh} / \mathrm{TiONT}$ case, formic acid was also detected as a product [101]. It was suggested that it is formed as formate species react with rhodium hydride:

$$
\mathrm{HCOO}_{(\mathrm{a})}+\mathrm{H}_{(\mathrm{a})} \rightarrow \mathrm{HCOOH}_{(\mathrm{g})}
$$

When Na-form titanates are used [94], the catalytic activity may be different. In the case of $\mathrm{CO}_{2}$ hydrogenation, Yu et al. [117] compared the activity of $\mathrm{Pt} / \mathrm{TiONT}$ and $\mathrm{Pt} / \mathrm{TiO}_{2}$ samples. In their test reaction, $\mathrm{Pt} / \mathrm{TiONT}$ catalysts exhibited a higher activity than $\mathrm{Pt} / \mathrm{TiO}_{2}$. The authors explained the activity of $\mathrm{Pt} / \mathrm{TiONT}$ with its higher $\mathrm{CO}_{2}$ adsorption capacity originating from its higher surface area and nanotubular morphology. Moreover, some active superficial species were identified by in situ infrared studies during the reaction. It has been reported previously that the presence of alkali metals in solid catalysts can induce the dissociation of $\mathrm{CO}_{2}[11,12,118]$. In the case of TiONT synthesized by the hydrothermal method, the $\mathrm{Na}^{+}$contained in its structure could promote the effective dissociation of $\mathrm{CO}_{2}$ on the catalyst surface; thus, the rate of $\mathrm{CO}_{2}$ hydrogenation could be higher.

In summary, we may conclude that the structure of the support has a significant influence on the activity of titania and titanate-like catalysts in $\mathrm{CO}_{2}$ hydrogenation. $\mathrm{Rh} / \mathrm{TiONW}$, which features a $\mathrm{TiO}_{2}(\mathrm{~B})$ phase at the reaction temperature has a higher activity than $\mathrm{Rh} / \mathrm{TiONT}$, in which the anatase structure is dominant at the reaction temperature. The Degussa $\mathrm{TiO}_{2}$, which has a mainly rutile structure, exhibited a somewhat higher steady state activity than $\mathrm{Rh} / \mathrm{TiONW}$, although the TOF values are almost the same. The ionic form of $\mathrm{Rh}$ located on titanate framework may contribute to the activation of $\mathrm{CO}_{2}$ and further reaction formate intermediates formed during catalytic reaction.

\section{2. $\mathrm{CO}+\mathrm{H}_{2} \mathrm{O}$ Reaction on $\mathrm{Rh} / \mathrm{TiONW}, \mathrm{Rh} / \mathrm{TiONT}$ and $\mathrm{Rh} / \mathrm{TiO}_{2}$}

Water gas, also known as synthesis gas, contains carbon monoxide $(\mathrm{CO})$ and hydrogen $\left(\mathrm{H}_{2}\right)$. The water gas shift (WGS) reaction is the intermediate step used for $\mathrm{CO}$ reduction and hydrogen enrichment in synthesis gas $[119,120]$. Italian physicist Felice Fontana discovered the water gas shift reaction in 1780, but its actual importance was realized much later. The water gas synthesis reaction is an important process to produce $\mathrm{CO}$-free hydrogen or to adjust the $\mathrm{H}_{2} / \mathrm{CO}$ ratio [121]. Adjusting the $\mathrm{H}_{2} / \mathrm{CO}$ ratio is especially required for downstream processes such as Fischer-Tropsch reactions and methanol synthesis [122].

Many catalysts were tested in the WGS reaction. According to the nature of the active component and the applied support, $\mathrm{CO}_{2}, \mathrm{H}_{2}$ and different hydrocarbons were formed [15,16]. Based on the kinetic results, two types of mechanisms were proposed [1]. In the oxidation-reduction, or regenerative mechanism of Rideal-Elay type, water oxidizes the surface and CO re-reduces the oxidized surface [123]. Others have suggested a bi-functional process where the $\mathrm{CO}$ adsorbed on the precious metal or the mixed metal oxide is oxidized by the support and then water fills the support oxygen vacancy [124]:

$$
\begin{aligned}
& \mathrm{H}_{2} \mathrm{O}+* \leftrightarrow \mathrm{H}_{2}+\mathrm{O}^{*} \\
& \mathrm{CO}+\mathrm{O}^{*} \leftrightarrow \mathrm{CO}_{2}+*
\end{aligned}
$$

where $*$ is an active site.

Another possible explanation is offered by the multi-step Langmuir-Hinshelwood type or "associative" mechanism where adsorbed or dissociated water forms reactive hydroxyl groups that combine with $\mathrm{CO}$ to produce a formate that decomposes to $\mathrm{CO}_{2}$ and $\mathrm{H}_{2}$. Others describe a bifunctional nature where $\mathrm{CO}$ adsorbed on the reduced metal migrates to react with hydroxyl groups in a 
bond-making reaction to produce the formate intermediate $[15,16,125,126]$. The FTIR analysis has been commonly used to confirm the presence of the formate intermediate:

$$
\begin{aligned}
& \mathrm{CO}+* \leftrightarrow \mathrm{CO}^{*} \\
& \mathrm{H}_{2} \mathrm{O}+2 \mathrm{a} \leftrightarrow \mathrm{H}^{*}+\mathrm{OH}^{*} \\
& \mathrm{OH}^{*}+\mathrm{CO}^{*} \leftrightarrow \mathrm{HCOO}^{*}+* \\
& \mathrm{HCOO}^{*}+* \leftrightarrow \mathrm{CO}_{2}{ }^{*}+\mathrm{H}^{*} \\
& \mathrm{CO}_{2}{ }^{*} \leftrightarrow \mathrm{CO}_{2}+* \\
& 2 \mathrm{H}^{*} \leftrightarrow \mathrm{H}_{2}+2 *
\end{aligned}
$$

At higher pressures corresponding to industrial conditions, it was necessary to include steps covering the synthesis and hydrogenation of formate [127]. In this hydrogenation reaction, methanol was produced:

$$
\begin{gathered}
\mathrm{HCOO}^{*}+\mathrm{H}^{*} \leftrightarrow \mathrm{H}_{2} \mathrm{COO}^{*} \\
\mathrm{H}_{2} \mathrm{COO}^{*}+4 \mathrm{H}^{*} \leftrightarrow \mathrm{CH}_{3} \mathrm{OH}_{(\mathrm{g})}+\mathrm{H}_{2} \mathrm{O}_{(\mathrm{g})}
\end{gathered}
$$

The catalytic reaction of water with carbon monoxide to form hydrocarbons and carbon dioxide is known as the Kölbel-Engerhardt reaction [128]. Earlier, this reaction was investigated over supported rhodium $[129,130]$. The formation of methane appears to occur via the water gas shift reaction, followed by the hydrogenation of surface carbon:

$$
\begin{gathered}
\mathrm{CO}+2 \mathrm{~s} \leftrightarrow \mathrm{C}_{\mathrm{s}}+\mathrm{O}_{(\mathrm{a})} \\
\mathrm{H}_{2} \mathrm{O}+2 \mathrm{~s} \leftrightarrow \mathrm{OH}_{(\mathrm{a})}+\mathrm{H}_{(\mathrm{a})} \\
\mathrm{C}_{\mathrm{s}}+4 \mathrm{H}_{(\mathrm{a})} \leftrightarrow \mathrm{CH}_{4(\mathrm{~g})}
\end{gathered}
$$

The turnover frequency for this reaction was a function of the support type, resulting in the turnover frequency sequence at $600 \mathrm{~K}: \mathrm{Rh} / \mathrm{Al}_{2} \mathrm{O}_{3}>\mathrm{Rh} / \mathrm{Y}$ zeolite $>\mathrm{Rh} / \mathrm{SiO}_{2}>\mathrm{Rh} / \mathrm{NaY}$ zeolite [129].

The $\mathrm{CO}+\mathrm{H}_{2} \mathrm{O}$ reaction was investigated on $\mathrm{Rh}$ catalysts using titanate and titania supports. The main products were hydrogen and carbon dioxide; only a very small amount of methane was formed on titania-like supports. The catalytic activity of $\mathrm{Rh} / \mathrm{TiO}_{2}, \mathrm{Rh} / \mathrm{TiONW}$ and $\mathrm{Rh} / \mathrm{TiONT}$ was tested and compared at $550 \mathrm{~K}$. The conversion data are displayed in Figure 12. The $\mathrm{CO}_{2}$ formation rates are shown in Figure 13. The $\mathrm{H}_{2}$ formation rate exhibited a similar trend (not shown). The highest conversion was measured on $1 \% \mathrm{Rh} / \mathrm{TiO}_{2}$ (Degussa P25). The steady-state activity of $1 \% \mathrm{Rh} / \mathrm{TiONW}$ was higher than on $1 \% \mathrm{Rh} / \mathrm{TiONT}$. A similar trend was found when we compared the formation rates. Although the conversion and the formation rate were the highest on $1 \% \mathrm{Rh} / \mathrm{TiO}_{2}$, the turnover frequencies showed no significant deviation (Table 3). The effect of Au additive was also investigated. The Au/titanates were not active in the reaction.

Table 3. Activity data obtained in the $\mathrm{CO}+\mathrm{H}_{2} \mathrm{O}$ reaction over different catalysts in the quasi steady-state reaction.

\begin{tabular}{ccccc}
\hline & $\begin{array}{c}\mathbf{D} \\
\mathbf{\%}\end{array}$ & $\begin{array}{c}\mathbf{K} \\
\mathbf{\%}\end{array}$ & $\begin{array}{c}\mathbf{W C O}_{\mathbf{2}} \\
\mathbf{n m o l} / \mathbf{g s}\end{array}$ & $\begin{array}{c}\mathbf{T O F ~ C O}_{\mathbf{2}} \\
\mathbf{s}^{\mathbf{- 1}}\end{array}$ \\
\hline $1 \% \mathrm{Rh} / \mathrm{TiO}_{2}$ & 36 & 11.4 & 1078.1 & $30.8^{*} 10^{-3}$ \\
$1 \% \mathrm{Rh} / \mathrm{TiONT}$ & 10 & 3.4 & 295.6 & $30.4^{*} 10^{-3}$ \\
$1 \% \mathrm{Rh} / \mathrm{TiONW}$ & 29 & 4.7 & 456.8 & $16.2^{*} 10^{-3}$ \\
$1 \%(\mathrm{Rh}+\mathrm{Au}) \mathrm{TiONW}$ & 33 & 1.9 & 176.8 & $5.5^{*} 10^{-3}$ \\
\hline
\end{tabular}




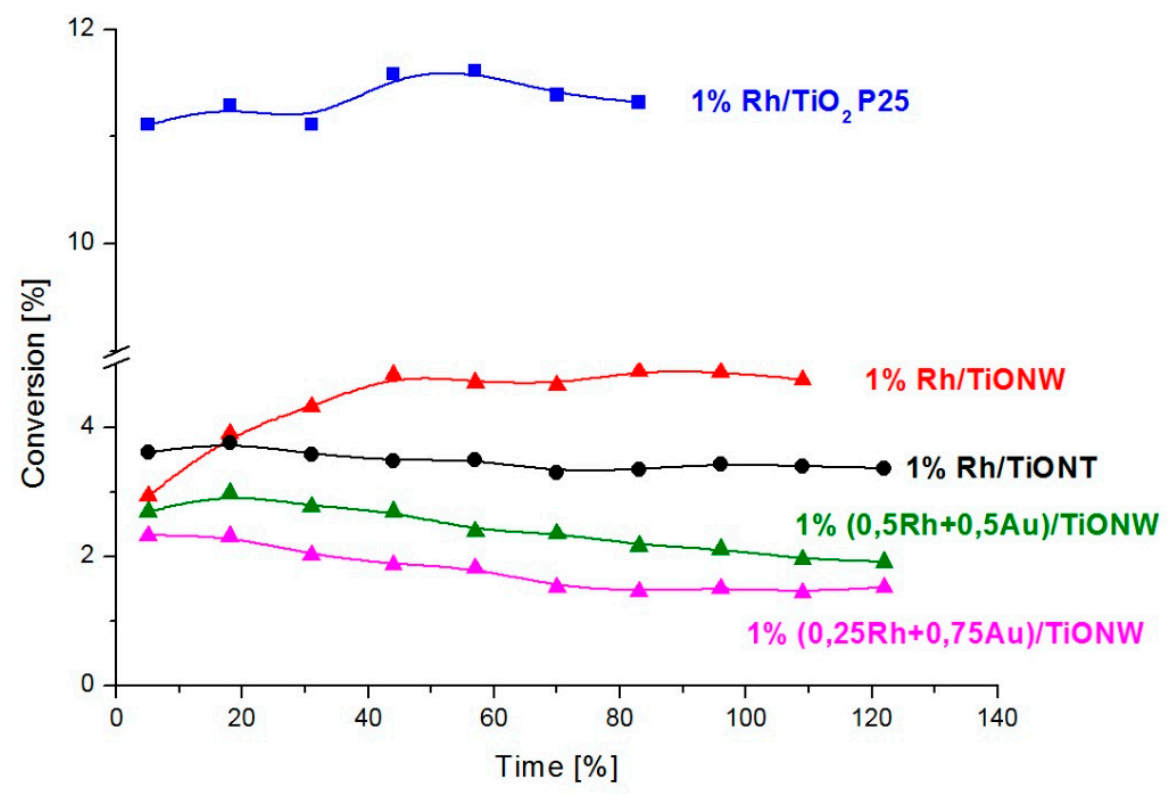

Figure 12. Conversion of the $\mathrm{CO}+\mathrm{H}_{2} \mathrm{O}$ reaction over $1 \% \mathrm{Rh} / \mathrm{TiO}_{2}$ (Degussa $\mathrm{P} 25$ ), $1 \% \mathrm{Rh} / \mathrm{TiONW}$, $1 \% \mathrm{Rh} / \mathrm{TiONT}, 1 \%(0.25 \mathrm{Rh}+0.75 \mathrm{Au}) / \mathrm{TiONW}$ and over $1 \%(0.5 \mathrm{Rh}+0.5 \mathrm{Au}) / \mathrm{TiONW}$. The reaction temperature was $550 \mathrm{~K}$.

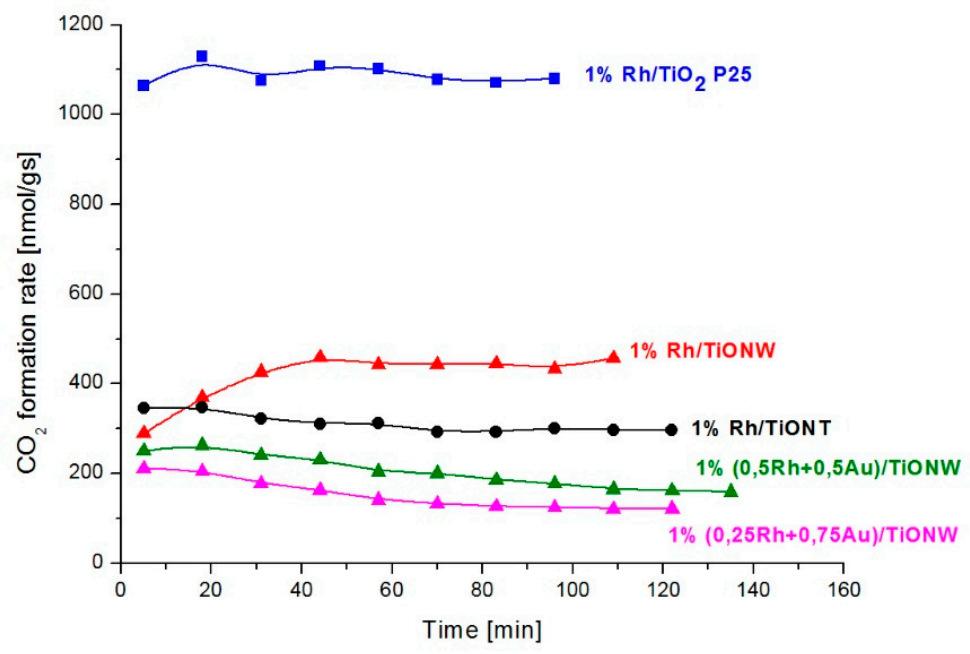

Figure 13. $\mathrm{CO}_{2}$ formation rate in the $\mathrm{CO}+\mathrm{H}_{2} \mathrm{O}$ reaction over different $\mathrm{Rh}$ catalysts at $550 \mathrm{~K}$.

As the reaction products were almost exclusively $\mathrm{CO}_{2}$ and hydrogen, we suggest that both the oxidation-reduction or regenerative mechanism of the Rideal-Elay type, and the multi-step Langmuir-Hinshelwood type or "associative" mechanism operate on titania- and titanate-supported Rh catalyst. The oxygen mobility, mainly in titanate supports, is high enough to subtract oxygen. Since formate intermediates are easily formed and stabilized on these supports or at the metal-support interface, the $\mathrm{CO}_{2}$ formation can be explained by the decomposition of formate. As we discussed above, the $\mathrm{Rh}$ ion in the titanates may catalyze the reaction efficiently via the oxidation-reduction mechanism. Interestingly, the TOF values are the same for both $\mathrm{Rh} / \mathrm{TiO}_{2}$ and $\mathrm{Rh} / \mathrm{TiONT}$. This means that the number of $\mathrm{Rh}$ is higher on $\mathrm{Rh} / \mathrm{TiO}_{2}$ but the activities of $\mathrm{Rh}$ sites are the same.

The co-deposited gold suppressed the catalytic activity, as was detected in $\mathrm{CO}_{2}$ hydrogenation, indicating that gold covers the active Rh sites. The observed smaller activity can be attributed to the $\mathrm{Rh}$ particles which were segregated from the $\mathrm{Au}-\mathrm{Rh}$ core-shell cluster due to $\mathrm{CO}$ as a reaction partner of the WGS reaction. The reaction mixture destroys the core-shell structure, as discussed above. 


\section{3. $\mathrm{CH}_{5} \mathrm{OH}$ Decomposition}

The increasing demand for alternative energy sources has drawn great attention to $\mathrm{H}_{2}$ production by ethanol transformation [17-19]. The use of ethanol is favored because it can be readily produced from renewable biomass. Supported noble metals are active catalysts in the transformation. Both the nature of the metal and the support determine the product distribution. Alumina-supported catalysts are very active at low temperatures in the dehydrogenation of ethanol to ethylene. At high temperatures, ethanol is converted into $\mathrm{H}_{2}, \mathrm{CO}, \mathrm{CO}_{2}$ and $\mathrm{CH}_{4}$. $\mathrm{Rh}$ was significantly more active and selective towards hydrogen formation than $\mathrm{Ru}, \mathrm{Pt}$ and $\mathrm{Pd}$ [131-138]. Ethylene formation was not detected when a ceria-type support was used [132]. When titania was the support, aldehyde formation was also significant $[134,135,137]$. The surface chemistry of ethanol on Rh single crystal was also investigated in detail $[139,140]$. We now compare the performance of Rh supported on different nanostructured titanates (TiONW and TiONT) as the catalyst of the ethanol transformation reaction.

The $1 \% \mathrm{Rh} / \mathrm{TiO}_{2}$ showed a high conversion at $603 \mathrm{~K}$ at the first stage of the reaction: at $5 \mathrm{~min}$, the conversion reached $93 \%$. With an increasing reaction time, the conversion dropped significantly (Figure 14). The steady state activity was obtained with $\sim 40 \%$ conversion at around $120 \mathrm{~min}$.

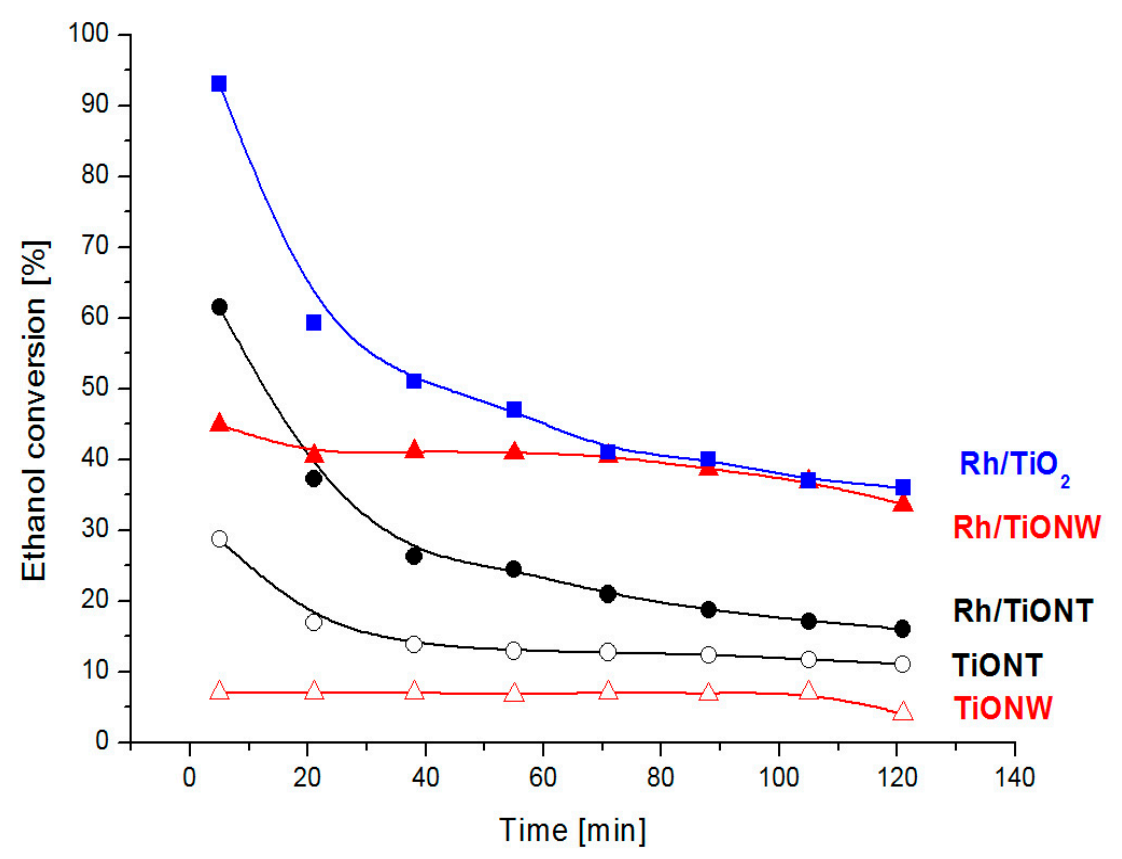

Figure 14. Ethanol conversion over titania and titanate supported Rh catalysts at $603 \mathrm{~K}$.

When nanostructured titanates were applied, the activities were smaller. In the case of $1 \%$ $\mathrm{Rh} / \mathrm{TiONT}$, the initial conversion was around $60 \%$ and it decreased with time; the steady state activity was obtained at around 100 min with $20 \%$ conversion. Interestingly, the Rh/TiONW activity was higher than that of Rh/TiONT without any major activity decrease (Figure 14). The steady state activity was the same as that measured over $\mathrm{Rh} / \mathrm{TiO}_{2}$. Acetaldehyde, hydrogen, carbon monoxide, methane, ethylene and diethyl ether were the reaction products on all titania and titanate supported Rh catalysts. Very small amounts of aceton and acetic acid were also detectable occasionally. High acetaldehyde selectivity was detected in all cases, which indicates that the acetaldehyde forms via the oxidative dehydrogenation of ethanol as was assumed earlier on reducible oxide supports, including $\mathrm{TiO}_{2}$ [133]. The relatively lower catalytic activity of Rh/TiONT can be explained by the tube structure; the diameter of the tube prevents the ethanol from reaching the active sites inside the tube.

The selectivity data at 5 and $105 \mathrm{~min}$ of the reaction are presented in Table 4 . On $\mathrm{Rh} / \mathrm{TiO}_{2}$, acetaldehyde selectivity increased with time and hydrogen selectivity decreased. This decrease was less pronounced on both $\mathrm{Rh} / \mathrm{TiONW}$ and $\mathrm{Rh} / \mathrm{TiONT}$ where the hydrogen selectivity at steady state 
activity was $\sim 10 \%$. This hydrogen selectivity value is significantly higher than that on $\mathrm{Rh} / \mathrm{TiO}_{2}$. The ethylene and diethyl ether selectivity was low in all cases.

Table 4. Conversion and selectivity data measured in the ethanol transformation reaction on titaniaand titanate-supported Rh catalysts.

\begin{tabular}{|c|c|c|c|c|c|c|c|c|c|c|}
\hline \multirow[b]{3}{*}{$\min$} & \multirow{2}{*}{\multicolumn{2}{|c|}{$\begin{array}{c}\text { Conversion } \\
\%\end{array}$}} & \multicolumn{8}{|c|}{$\begin{array}{c}\text { Selectivity } \\
\%\end{array}$} \\
\hline & & & \multicolumn{2}{|c|}{$\mathrm{C}_{2} \mathrm{H}_{4}$} & \multicolumn{2}{|c|}{$\mathrm{C}_{2} \mathrm{H}_{4} \mathrm{O}$} & \multicolumn{2}{|c|}{$\mathbf{H}_{2}$} & \multicolumn{2}{|c|}{$\left(\mathrm{C}_{2} \mathrm{H}_{5}\right) \mathrm{O}$} \\
\hline & 5. & 105. & 5. & 105. & 5. & 105. & 5. & 105. & 5. & 105. \\
\hline $\mathrm{Rh} / \mathrm{TiO}_{2}$ & 93 & 37 & 6.9 & 1.8 & 77.8 & 95.7 & 13.6 & 5.8 & 7 & 0.1 \\
\hline Rh/TiONW & 44 & 36 & 0.4 & 0.2 & 86.6 & 94.7 & 12.5 & 10.8 & 3.7 & 0.6 \\
\hline Rh/TiONT & 61 & 17 & 0.4 & 0.3 & 78.0 & 91.3 & 25.0 & 10.6 & 1.0 & 3.6 \\
\hline TiONW & 1 & 7.1 & 3.2 & 3.4 & 66.7 & 66.1 & 5.0 & 0 & 26.0 & 28.0 \\
\hline TiONT & 28.7 & 11.7 & 23 & 0.8 & 93 & 96.0 & 6.0 & 0 & 1.0 & 2.4 \\
\hline
\end{tabular}

Infrared spectroscopy is a useful tool to identify surface intermediates formed during a catalytic reaction. An in situ DRIFTS study was performed in the presence of a reaction mixture at different temperatures. The spectra were qualitatively the same on all supported catalysts. Figure 15 shows the typical spectra obtained on $\mathrm{Rh} / \mathrm{TiOW}$. At $300 \mathrm{~K}$ absorption bands were observed at 2974, 2929 and $2875 \mathrm{~cm}^{-1}$ in the $\mathrm{C}-\mathrm{H}$ stretching region. In the low-frequency range, absorption bands were detected at $1448-1450$ and $1383-1384 \mathrm{~cm}^{-1}$ and both could be assigned as the symmetric and asymmetric $\mathrm{CH}_{3}$ vibrations of ethanol/ethoxide. The bands observed at 1140-1144, 1124-1121, 1069-1074, 1045-1047 $\mathrm{cm}^{-1}$ could be attributed to $v \mathrm{C}-\mathrm{O}$ and $\nu \mathrm{C}-\mathrm{C}$ vibrations of monodentate and bidentate ethoxide species [132-134]. The intensities of these bands decreased as the temperature increased but dramatic changes were not detected. At $\sim 1560 \mathrm{~cm}^{-1}$, a small intensity peak appeared at $423 \mathrm{~K}$, probably due to acetate species $\left(v_{a s} \mathrm{O}-\mathrm{C}-\mathrm{O}\right)$. This band appears with a higher intensity on $\mathrm{Al}_{2} \mathrm{O}_{3}$ and $\mathrm{CeO}_{2}$ supports [132-134].

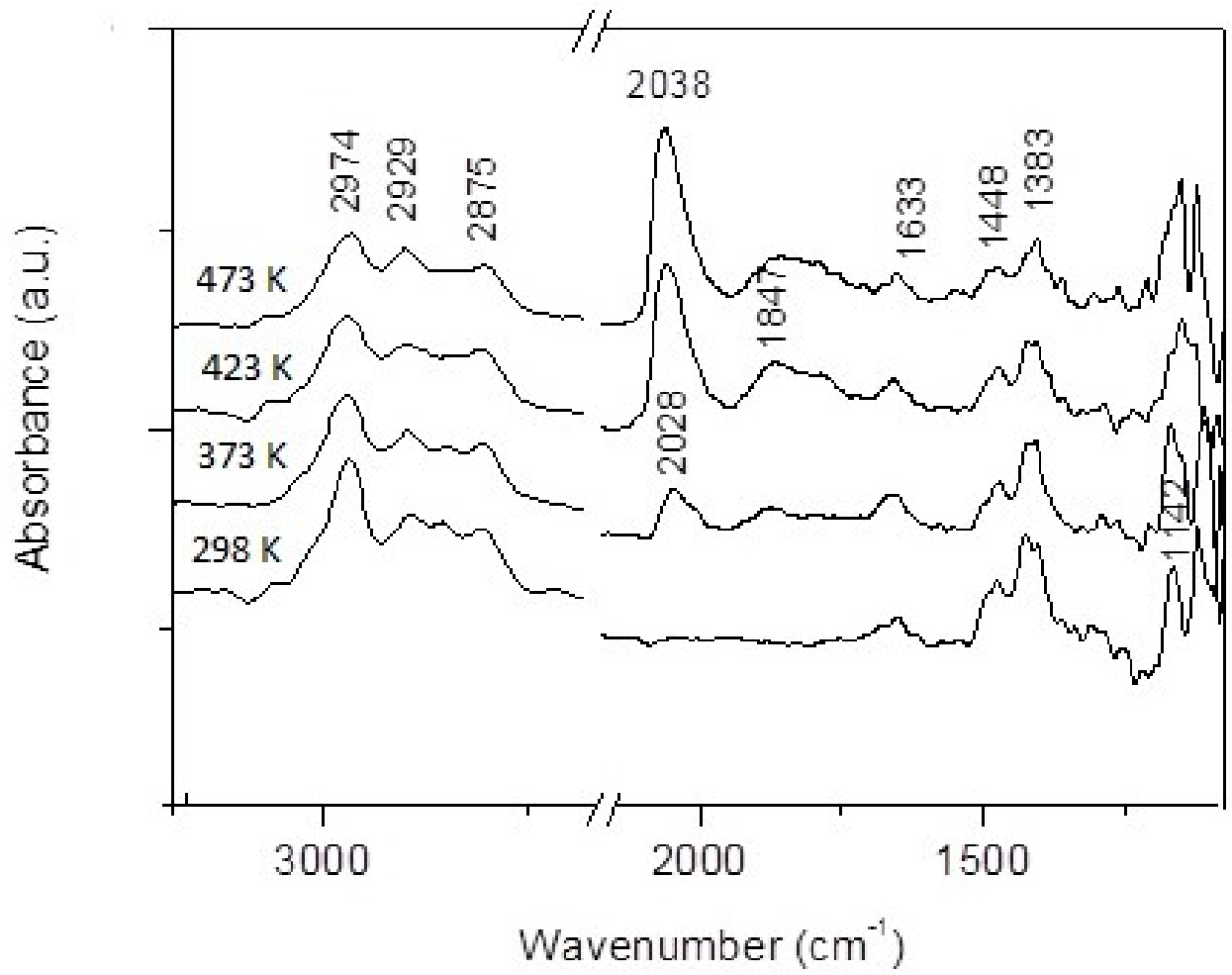

Figure 15. DRIFT spectra obtained on Rh/TiONW during ethanol decomposition at different temperatures. 
Apart from the ethanol/ethoxide bands, a peak at $1633 \mathrm{~cm}^{-1}$ started developing at $297 \mathrm{~K}$. Its intensity increased slightly with temperature. This band is present in many cases in ethanol decomposition, oxidation and ethanol steam reformation [141,142]. It was attributed to the $v C-O$ vibration in acetyl $\left(\mathrm{CH}_{3} \mathrm{CO}\right)$ species. When the $\mathrm{Rh} / \mathrm{TiO}_{2}$ was treated with ethanol above $373 \mathrm{~K}$, new peaks were detected at 2028 and $1847 \mathrm{~cm}^{-1}$. The intensities of these bands increased by increasing the temperature and the peak observed at $2028 \mathrm{~cm}^{-1}$ at room temperature shifted to higher wave numbers. The absorbance at $1847 \mathrm{~cm}^{-1}$ could be attributed to bridge bonded CO on Rh sites [77,91]. The feature of the adsorbed CO detected at $2028-2038 \mathrm{~cm}^{-1}$ is significantly differing from that depicted in Figure 4 . This discrepancy could be explained by the Rh carbonyl hydride formation (H-Rh-CO) [143]. The adsorbed CO desorbs in a desorption rate-limiting step.

Taking into account the reaction products and the surface intermediates formed during the reaction, we offer the following reaction steps which were proved in many cases. After the initial step, the formation of ethoxide, further dehydrogenation occurs:

$$
\begin{aligned}
& \mathrm{C}_{2} \mathrm{H}_{5} \mathrm{OH}_{(\mathrm{a})} \rightarrow \mathrm{C}_{2} \mathrm{H}_{5} \mathrm{O}_{(\mathrm{a})}+\mathrm{H}_{(\mathrm{a})} \\
& \mathrm{C}_{2} \mathrm{H}_{5} \mathrm{O}_{(\mathrm{a})} \rightarrow \mathrm{CH}_{3} \mathrm{CHO}_{(\mathrm{a})}+\mathrm{H}_{(\mathrm{a})}
\end{aligned}
$$

The acetaldehyde mostly desorbs as reaction product and a smaller fraction decomposes forming acetyl:

$$
\mathrm{CH}_{3} \mathrm{CHO}_{(\mathrm{a})} \rightarrow \mathrm{CH}_{3} \mathrm{CO}_{(\mathrm{a})}+\mathrm{H}_{\mathrm{a})}
$$

In the acetyl species, the $\mathrm{C}-\mathrm{C}$ rupture easily happens, forming adsorbed $\mathrm{CO}$ and methyl radicals. $\mathrm{Rh}$ is considered to be among the best metals for hydrogen production due to its high activity for $\mathrm{C}-\mathrm{C}$ cleavage in ethanol. The methyl radical either decomposes further or reacts with hydrogen and finally methane is produced. The adsorbed hydrogen recombines into $\mathrm{H}_{2}$. As the hydrogen selectivity was two times higher on both $\mathrm{Rh} / \mathrm{TiONW}$ and $\mathrm{Rh} / \mathrm{TiONT}$ than on $\mathrm{TiO}_{2} \mathrm{P} 25$, the decomposition of acetyl intermediate could be catalyzed by $\mathrm{Rh}^{+}$, which is absent on commercial $\mathrm{TiO}_{2}$ :

$$
\begin{gathered}
\mathrm{CH}_{3} \mathrm{CO}_{(\mathrm{a})} \rightarrow \mathrm{CH}_{3(\mathrm{a})}+\mathrm{CO}_{(\mathrm{a})} \\
\mathrm{CH}_{3(\mathrm{a})}+\mathrm{H}_{(\mathrm{a})} \rightarrow \mathrm{CH}_{4} \\
\mathrm{CH}_{3(\mathrm{a})} \rightarrow \mathrm{CH}_{(\mathrm{a})}+\mathrm{H}_{2}
\end{gathered}
$$

During ethanol decomposition, very small amounts of ethylene and diethyl ether were also detected. In this process, the first step involves the formation of diethyl ether because of intermolecular dehydrogenation between two ethanol molecules [144]:

$$
2 \mathrm{C}_{2} \mathrm{H}_{5} \mathrm{OH}_{(\mathrm{a})} \rightarrow \mathrm{C}_{2} \mathrm{H}_{5}-\mathrm{O}-\mathrm{C}_{2} \mathrm{H}_{5(\mathrm{a})}+2 \mathrm{OH}_{(\mathrm{a})}
$$

This is followed by a second dehydrogenation of diethyl ether to ethylene:

$$
\mathrm{C}_{2} \mathrm{H}_{5}-\mathrm{O}-\mathrm{C}_{2} \mathrm{H}_{5(\mathrm{a})} \rightarrow 2 \mathrm{C} 2 \mathrm{H} 4+2 \mathrm{OH}_{(\mathrm{a})}
$$

Summing up, we may conclude that the structure of nanotitanates influences the steady state conversion of ethanol to some extent. The conversion was equal on $\mathrm{Rh} / \mathrm{TiO}_{2}$ and $\mathrm{Rh} / \mathrm{TiONW}$, but lower on $\mathrm{Rh} / \mathrm{TiONT}$ where the decomposition may sterically hindered by the tubular structure of TiONT. In all cases, acetaldehyde was the main product. It is remarkable that on $\mathrm{Rh}$ supported on nanostructured titanates, the hydrogen selectivity was double the steady state conditions. IR studies verified that the ethoxide dehydrogenates and most of the acetaldehyde desorbs as product but some of it dehydrogenates further and $\mathrm{C}-\mathrm{C}$ bond rupture occurs via the acetyl surface intermediate. 


\section{Summary}

$\mathrm{Rh}$ accelerated the transformation of titanate nanotubes to anatase. The strong interaction between $\mathrm{Rh}$ (in ionic form, discussed above) and titanate structure plays an important role in catalytic effects. In addition to this interaction, the structure of titanates moderates the catalytic activity. Rh-decorated nanowires transform into the $\mathrm{TiO}_{2}(\mathrm{~B})$ phase and the nanotubes transform to anatase. The $\mathrm{Rh}$-assisted processes started from $550 \mathrm{~K}$ where the titanate-supported $\mathrm{Rh}$ catalysts exhibited a remarkable catalytic effect in $\mathrm{CO}_{2}$ hydrogenation, $\mathrm{CO}+\mathrm{H}_{2} \mathrm{O}$ reaction and in ethanol decomposition. In all cases, the use of $\mathrm{TiO}_{2} \mathrm{P} 25$ (which contains mostly rutile phase) performed the highest activity at steady-state conditions.

The activity order of the supported Rh samples in the first minutes of the reaction decreased in the order $\mathrm{Rh} / \mathrm{TiONW}>\mathrm{Rh} / \mathrm{TiO}{ }_{2}>\mathrm{Rh} / \mathrm{TiONT}$ in $\mathrm{CO}_{2}$ hydrogenation. $\mathrm{Rh} / \mathrm{TiO}_{2}$ displayed the highest steady-state activity. The conversion of $\mathrm{CO}_{2}$ on $\mathrm{Rh} / \mathrm{TiONW}$ decreased significantly in time but in the other cases, the $\mathrm{CO}_{2}$ consumption was relatively constant. The reaction ran in all cases via the formation of a formate intermediate in $\mathrm{CO}_{2}$ methanation. On both nanostructured titanates, "tilted $\mathrm{CO}^{\prime \prime}$ species were also formed, which facilitates $\mathrm{H}$-assisted $\mathrm{C}-\mathrm{O}$ bond rupture. Positively charged $\mathrm{Rh}$ ion may help the activation of $\mathrm{CO}_{2}$ and accelerate the further decomposition of formate intermediates yielding $\mathrm{CH}_{4}$.

In the $\mathrm{CO}+\mathrm{H}_{2} \mathrm{O}$ reaction, the highest conversion was obtained on $\mathrm{Rh} / \mathrm{TiO}_{2}$ Degussa P25 catalyst. It is very interesting that the turnover frequencies obtained in the case of $\mathrm{Rh} / \mathrm{TiONT}, \mathrm{Rh} / \mathrm{TiONW}$ and $\mathrm{Rh} / \mathrm{TiO}_{2}$ were almost the same. From this comparison, we may suggest that the number of $\mathrm{Rh}$ is higher on $\mathrm{Rh} / \mathrm{TiO}_{2}$ but the activities of $\mathrm{Rh}$ sites are the same. As the reaction products were almost exclusively $\mathrm{CO}_{2}$ and hydrogen, we suggest that both oxidation-reduction or regenerative mechanism of the Rideal-Elay type, and a multi-step Langmuir-Hinshelwood type or "associative" mechanism operate. The oxygen mobility, mainly in titanate supports, is high enough to subtract oxygen for the reaction.

In ethanol decomposition, the $\mathrm{Rh} / \mathrm{TiO}_{2}$ and $\mathrm{Rh} / \mathrm{TiONW}$ exhibited an equal steady-state activity. The relatively lower catalytic activity in the case of $\mathrm{Rh} / \mathrm{TiONT}$ can be explained by the tube structure: the diameter of the tube inhibits the diffusion the ethanol reaching the active sites inside the tube. In all cases, acetaldehyde was the main product. A small fraction of acetaldehyde transforms to acetyl intermediates with help of $\mathrm{Rh}^{+}$. The $\mathrm{C}-\mathrm{C}$ breaking in acetyl species leads to the formation of hydrogen. It is remarkable that on nanostructured titanates, the hydrogen selectivity was two times higher than on $\mathrm{Rh} / \mathrm{TiO}_{2}$ at steady-state conditions.

The $\mathrm{TiO}_{2}$ (Degussa P25) contains a dominantly rutile structure (rutile/anatase ratio is roughly 75/25). The $\mathrm{Rh} / \mathrm{TiONW}$ performs a significant $\beta-\mathrm{TiO}_{2}$ phase at reaction conditions. The $\mathrm{Rh} / \mathrm{TiONT}$ transforms mainly to anatase structure. From the comparison of conversion data of the studied reactions, we conclude that the rutile structure shows the highest activity. In steady-state conditions, the rutile structure exhibits almost the same activity than the $\mathrm{TiO}_{2}(\mathrm{~B})$ phase in $\mathrm{CO}_{2}$ methanation and ethanol decomposition. In the case of $\mathrm{Rh} / \mathrm{TiONT}$ where the anatase phase is dominant, less activity was measured in all three reactions.

The tube morphology in titanate nanotubes case may also influence the catalytic activity; the diffusion of reactants and the products could be different on the outside and the inside of the tubes.

The gold adatoms decrease the activity of Rh due to the formation of core-shell structure where the gold is on top. The observed activity can be attributed to the partial disruption of the structure by the reactants and the lower activity of the remaining Au nanoparticles in the topmost layer.

Author Contributions: All authors contributed to write the review. All authors have read and agreed to the published version of the manuscript.

Funding: This research received no external funding.

Acknowledgments: The authors wish to thank Péter Pusztai and Kornelia Baán for executing the electron microscopic and infrared measurements and András Erdőhelyi for fruitful discussions. Financial support of this work by the National Research Development and Innovation Office through grants GINOP-2.3.2-15-2016-00013 
and NKFIH OTKA K120115 (Zoltán Kónya), K126065 (Ákos Kukovecz) and PD 120877 (András Sápi) are gratefully acknowledged.

Conflicts of Interest: The authors declare no conflict of interest.

\section{References}

1. Ertl, G.; Knözinger, H.; Weitkamp, J. Handbook of Heterogeneous Catalysis; VCH: Weinheim, German, 1997; p. 2478.

2. Wang, W.; Wang, S.; Ma, X.; Gong, J. Recent advances in catalytic hydrogenation of carbon dioxide. Chem. Soc. Rev. 2011, 40, 3703-3727. [CrossRef]

3. Centi, G.; Quadrelli, E.A.; Perathoner, S. Catalysis for $\mathrm{CO}_{2}$ conversion: A key technology for rapid introduction of renewable energy in the value chain of chemical industries. Energy Environ. Sci. 2013, 6, 1711-1731. [CrossRef]

4. Artz, J.; Müller, T.E.; Thenert, K.; Kleinekorte, J.; Meys, R.; Sternberg, A.; Bardow, A.; Leitner, W. Sustainable conversion of carbon dioxide: An integrated review of catalysis and life cycle assessment. Chem. Rev. 2017, 118, 434-504. [CrossRef]

5. Kondratenko, E.V.; Mul, G.; Baltrusaitis, J.; Larrazábal, G.O.; Pérez-Ramírez, J. Status and perspectives of $\mathrm{CO}_{2}$ conversion into fuels and chemicals by catalytic, photocatalytic and electrocatalytic processes. Energy Environ. Sci. 2013, 6, 3112-3135. [CrossRef]

6. Studt, F.; Sharafutdinov, I.; Abild-Pedersen, F.; Elkjær, C.F.; Hummelshøj, J.S.; Dahl, S.; Chorkendorff, I.; Nørskov, J.K. Discovery of a Ni-Ga catalyst for carbon dioxide reduction to methanol. Nat. Chem. 2014, 6, 320-324. [CrossRef] [PubMed]

7. Porosoff, M.D.; Yan, B.; Chen, J.G. Catalytic reduction of $\mathrm{CO}_{2}$ by $\mathrm{H}_{2}$ for synthesis of $\mathrm{CO}$, methanol and hydrocarbons: Challenges and opportunities. Energy Environ. Sci. 2016, 9, 62-73. [CrossRef]

8. Leonzio, G. State of art and perspectives about the production of methanol, dimethyl ether and syngas by carbon dioxide hydrogenation. J. CO2 Util. 2018, 27, 326-354. [CrossRef]

9. Zheng, Y.; Zhang, W.; Li, Y.; Chen, J.; Yu, B.; Wang, J.; Zhang, L.; Zhang, J. Energy related $\mathrm{CO}_{2}$ conversion and utilization: Advanced materials/nanomaterials, reaction mechanisms and technologies. Nano Energy 2017, 40, 512-539. [CrossRef]

10. Frontera, P.; Macario, A.; Ferraro, M.; Antonucci, P. Supported catalysts for $\mathrm{CO}_{2}$ methanation: A review. Catalysts 2017, 7, 59. [CrossRef]

11. Freund, H.J.; Roberts, M.W. Surface chemistry of carbon dioxide. Surf. Sci. Rep. 1996, 25, 225-273. [CrossRef]

12. Kiss, J.; Révész, K.; Solymosi, F. Photoelectron Spectroscopic Studies of the Adsorption of $\mathrm{CO}_{2}$ on Potassium-Promoted Rh(111). Surf. Sci. 1988, 207, 36-54. [CrossRef]

13. László, B.; Baán, K.; Varga, E.; Oszkó, A.; Erdőhelyi, A.; Kónya, Z.; Kiss, J. Photo-induced reactions in the $\mathrm{CO}_{2}$-methane system on titanate nanotubes modified with Au and Rh nanoparticles. Appl. Catal. B Environ. 2016, 199, 473-484. [CrossRef]

14. Kiss, J.; Kukovecz, Á.; Kónya, Z. Beyond Nanoparticles; The Role of Sub-nanosized Metal Species in Heterogeneous Catalysis. Catal. Lett. 2019, 149, 1441-1454. [CrossRef]

15. Pal, D.B.; Chand, R.; Upadhyay, S.N.; Mishra, P.K. Performance of water gas shift reaction catalysts: A Review. Renew. Sustain. Energy Rev. 2018, 93, 549-565. [CrossRef]

16. Ratnasamy, C.; Wagner, J.P. Water Gas Shift Catalysis. Catal.Rev. 2009, 51, 325-440. [CrossRef]

17. Mattos, L.V.; Jacobs, G.; Davis, B.H.; Noronha, F.B. Production of hydrogen from ethanol: Review of reaction mechanism and catalytic deactivation. Chem. Rev. 2012, 112, 4094-4123. [CrossRef]

18. Contreras, J.L.; Salmones, J.; Colin-Luna, J.A.; Nuno, L.; Quintana, B.; Cordova, I.; Zeifert, B.H.; Tapia, C.; Fuentes, G. A. Cataysts for $\mathrm{H}_{2}$ production using the ethanol steam reforming (a review). Int. J. Hydrog. Energy 2014, 39, 18835-18853. [CrossRef]

19. Punase, K.D.; Rao, N.; Vija, P. A review on mechanistic kinetic models of ethanol steam reforming for hydrogen production using a fixed bed reactor. Chem. Pap. 2019, 73, 1027-1042. [CrossRef]

20. Solymosi, F.; Erdőhelyi, A.; Bánsági, T. Methanation of $\mathrm{CO}_{2}$ on supported rhodium catalyst. J. Catal. 1981, 68, 371-382. [CrossRef]

21. Henderson, M.A.; Worley, S.D. An infrared study of the hydrogenation of carbon dioxide on supported rhodium catalysts. J. Phys. Chem. 1985, 89, 1417-1423. [CrossRef] 
22. Trovarelli, A.; Mustazza, C.; Dolcetti, G.; Kaspar, F.; Grazioni, M. Carbon-dioxide hydrogenation on Rhodium supported on transition-metal oxides-effect of reduction temperature on product distribution. Appl. Catal. 1990, 65, 129-142. [CrossRef]

23. Solymosi, F.; Tombácz, I.; Koszta, J. Effect of variation of electric properties of $\mathrm{TiO}_{2}$ support on hydrogenation of $\mathrm{CO}$ and $\mathrm{CO}_{2}$ over Rh catalysts. J. Catal. 1985, 95, 578-586. [CrossRef]

24. Zhang, Z.L.; Kladi, A.; Verykios, X.E. Effects of Carrier Doping on Kinetic Parameters of $\mathrm{CO}_{2}$ Hydrogenation on Supported Rhodium Catalysts. J. Catal. 1994, 148, 737-747. [CrossRef]

25. Diebold, U. The surface science of titanium dioxide. Surf. Sci. Rep. 2003, 48, 53-229. [CrossRef]

26. Henderson, M.A. A surface science perspective on photocatalysis. Surf. Sci. Rep. 2011, 66, $185-297$. [CrossRef]

27. Wang, L.; Sasaki, T. Titanium Oxide Nanosheets: Graphene Analogues with Versatile Functionalities. Chem. Rev. 2014, 114, 9455-9486. [CrossRef]

28. Peña, M.A.; Fierro, J.L.G. Chemical Structures and Performance of Perovskite Oxides. Chem. Rev. 2001, 101, 1981-2018. [CrossRef]

29. Roy, P.; Berger, S.; Schmuki, P. TiO 2 nanotubes: Synthesis and applications. Angew. Chem. Int. Ed. Engl. 2011, 50, 2904-2939. [CrossRef]

30. Macák, J.M.; Tsuchiya, H.; Schmiuki, P. High-aspect-ratio $\mathrm{TiO}_{2}$ nanotubes by anodization of titanium. Angew. Chem. Int. Ed. Engl. 2005, 44, 2100-2102. [CrossRef]

31. Bavykin, D.V.; Lapkin, A.A.; Plucinski, P.K.; Friderich, J.M.; Walsh, F.C. Reversible Storage of Molecular Hydrogen by Sorption into Multilayered $\mathrm{TiO}_{2}$ Nanotubes. J. Phys. Chem. B 2005, 109, 19422-19427. [CrossRef]

32. Huang, R.W.J.M.; Chung, F.; Kelder, E.M. Impedance Simulation of a Li-Ion Battery with Porous Electrodes and Spherical $\mathrm{Li}^{+}$. Intercalation Part. J. Electrochem. Soc. 2006, 153, A1459-A1465. [CrossRef]

33. Kukovecz, Á.; Pótári, G.; Oszkó, A.; Kónya, Z.; Erdőhelyi, A.; Kiss, J. Probing the interaction of Au, Rh and bimetallic Au-Rh clusters with the $\mathrm{TiO}_{2}$ nanowire and nanotube support. Surf. Sci. 2011, 605, 1048-1055. [CrossRef]

34. Madarász, D.; Pótári, G.; Sápi, A.; László, B.; Csudai, C.; Oszkó, A.; Kukovecz, Á.; Erdőhelyi, A.; Kónya, Z.; Kiss, J. Metal loading determines the stabilization pathway for $\mathrm{Co}^{2+}$ in the titanate nanowires: Ion exchange vs. cluster formation. J. Phys. Chem. Chem. Phys. 2013, 15, 15917-15925. [CrossRef] [PubMed]

35. Kasuga, T.; Hiramatsu, M.; Hoson, A.; Sekino, T.; Niihara, K. Formation of Titanium Oxide Nanotube. Langmuir 1998, 14, 3160-3163. [CrossRef]

36. Horváth, E.; Kukovecz, Á.; Kónya, Z.; Kiricsi, I. Hydrothermal Conversion of Self-Assembled Titanate Nanotubes into Nanowires in a Revolving Autoclave. Chem. Mater. 2007, 19, 927-931. [CrossRef]

37. Kukovecz, Á.; Hodos, M.; Horváth, E.; Radnóczi, G.; Kónya, Z.; Kiricsi, I. Oriented Crystal Growth Model Explains the Formation of Titania Nanotubes. J. Phys. Chem. B 2005, 109, 17781-17783. [CrossRef] [PubMed]

38. Torrente-Murciano, L.; Lapkin, A.A.; Chadwick, D. Synthesis of high aspect ratio titanate nanotubes. J. Mater. Chem. 2010, 20, 6484-6489. [CrossRef]

39. Sun, X.; Li, Y. Synthesis and Characterization of Ion-Exchangeable Titanate Nanotubes. Chem. Eur. J. 2003, 9, 2229-2238. [CrossRef]

40. Cesano, F.; Bertarione, S.; Uddin, M.J.; Agostini, G.; Scarano, D.; Zeccina, A. Designing $\mathrm{TiO}_{2} \mathrm{Based}$ Nanostructures by Control of Surface Morphology of Pure and Silver Loaded Titanate Nanotubes. J. Phys. Chem. C 2010, 114, 169-178. [CrossRef]

41. Pusztai, P.; Puskás, R.; Varga, E.; Erdőhelyi, A.; Kukovecz, Á.; Kónya, Z.; Kiss, J. Influence of gold additives on the stability and phase transformation of titanate nanostructures. Phys. Chem. Chem. Phys. 2014, 16, 26786-26797. [CrossRef]

42. Bavykin, D.V.; Walsh, F.C. Titanate and Titania Nanotubes: Synthesis, Properties and Application; RSC Publishing: Cambridge, UK, 2010.

43. Kukovecz, Á.; Kordás, K.; Kiss, J.; Kónya, Z. Atomic scale characterization and surface chemistry of metal modified titanate nanotubes and nanowires. Surf. Sci. Rep. 2016, 71, 473-546. [CrossRef]

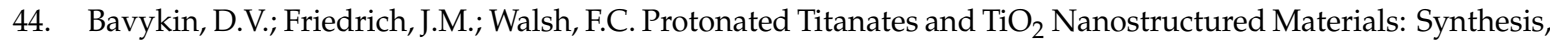
Properties, and Applications. Adv. Mater. 2006, 18, 2807-2824. [CrossRef]

45. Kiss, J.; Pusztai, P.; Óvári, L.; Baán, K.; Merza, G.; Erdőhelyi, A.; Kukovecz, Á.; Kónya, Z. Decoration of Titanate Nanowires and Nanotubes by Gold Nanoparticles: XPS, HRTEM and XRD Characterizatione. J. Surf. Sci. Nanotechnol. 2014, 12, 252-258. [CrossRef] 
46. Akita, T.; Okumura, M.; Tanaka, K.; Ohkuma, K.; Kohyama, M.; Koyanagi, T.; Data, M.; Tsubota, S.; Haruta, M. Transmission electron microscopy observation of the structure of $\mathrm{TiO}_{2}$ nanotube and $\mathrm{Au} / \mathrm{TiO} \mathrm{O}_{2}$ nanotube catalyst. Surf. Interf. Anal. 2005, 37, 265-269. [CrossRef]

47. Malwadkar, S.S.; Gholap, R.S.; Awate, S.V.; Korake, P.V.; Chaskar, M.G.; Gupta, N.M. Physico-chemical, photo-catalytic and $\mathrm{O}_{2}$-adsorption properties of $\mathrm{TiO}_{2}$ nanotubes coated with gold nanoparticles. Photochem. Photobiol. A Chem. 2009, 203, 24-31. [CrossRef]

48. Turki, A.; Kochkar, H.; Guillard, C.; Berhault, G.; Ghorbel, A. Effect of Na content and thermal treatment of titanate nanotubes on the photocatalytic degradation of formic acid. Appl. Catal. B Environ. 2013, 138-139, 401-415. [CrossRef]

49. Idakiev, V.; Yuan, Z.Y.; Tabakova, T.; Su, B.L. Titanium oxide nanotubes as supports of nano-sized gold catalysts for low temperature water-gas shift reaction. Appl. Catal. A Gen. 2005, 281, 149-155. [CrossRef]

50. Méndez-Cruz, M.; Ramírez-Solís, J.; Zanella, R. CO oxidation on gold nanoparticles supported over titanium oxide nanotubes. Catal. Today 2011, 166, 172-179. [CrossRef]

51. Zhu, B.; Guo, Q.; Huang, X.; Wang, S.; Zhang, S.; Wu, S.; Huang, W. Characterization and catalytic performance of $\mathrm{TiO}_{2}$ nanotubes-supported gold and copper particles. J. Mol. Catal. A Chem. 2006, 249, 211-217. [CrossRef]

52. László, B.; Baán, K.; Ferencz, Z.; Galbács, G.; Oszkó, A.; Kiss, J.; Kónya, Z.; Erdőhelyi, A. Gold size effect in the thermal-induced reaction of $\mathrm{CO}_{2}$ and $\mathrm{H}_{2}$ on titania and titanate nanotube-supported gold catalysts. J. Nanosci. Nanotechnol. 2019, 19, 470-477. [CrossRef]

53. László, B.; Baán, K.; Oszkó, A.; Erdőhelyi, A.; Kiss, J.; Kónya, Z. Hydrogen evolution in the photocatalytic reaction between methane and water in the presence of $\mathrm{CO}_{2}$ on titanate and titania supported $\mathrm{Rh}$ an $\mathrm{Au}$ catalysts. Top. Catal. 2018, 61, 875-888. [CrossRef]

54. Bavykin, D.V.; Lapkin, A.A.; Plucinski, P.K.; Torrente-Murciano, L.; Friedrich, J.M.; Walsh, F.C. Deposition of $\mathrm{Pt}, \mathrm{Pd}, \mathrm{Ru}$, and $\mathrm{Au}$ on the Surface of Titanate Nanotubes. Top. Catal. 2006, 39, 151-160. [CrossRef]

55. Fujishima, A.; Zhang, X.; Tryk, D.A. $\mathrm{TiO}_{2}$ photocatalysis and related surface phenomena. Surf. Sci. Rep. 2008, 63, 515-582. [CrossRef]

56. Kiatkittipong, K.; Scott, J.; Amal, R. Hydrothermal synthesized titanate nanostructures: Impact of heat treatment of particle characteristics and photocatalytic properties. ACS Appl. Mater. Inteface 2011, 3, 3988-3996. [CrossRef] [PubMed]

57. Pirila, M.; Lennkeri, R.; Goldman, W.M.; Kordas, K.; Huuhtanen, M.; Keiski, L. Photocatalytic Degradation of Butanol in Aqueous Solution by $\mathrm{TiO}_{2}$ Nanofibers. Top. Catal. 2013, 56, 630-636. [CrossRef]

58. Wu, M.-C.; Sapi, A.; Avila, A.; Szabó, M.; Hiltunen, J.; Tóth, G.; Kukovecz, Á.; Kónya, Z.; Keiski, R.; Su, W.-F.; Jantunen, $\mathrm{H}$.; et al. Enhanced Photocatalytic Activity of $\mathrm{TiO}_{2}$ Nanofiber and Their Flexible Composite Films: Decomposition of Organic Dyes and Efficent $\mathrm{H}_{2}$ Generationfrom Ethanol-Water Mixtures. Nano Res. 2011, 4, 360-369. [CrossRef]

59. Wu, M.-C.; Hiltunen, J.; Avila, A.; Larson, W.; Liao, H.-C.; Huuthanen, M.; Tóth, G.; Schhukarev, A.; Laufer, N.; Kukovecz, Á.; Kónya, Z.; et al. Nitrogen-Doped Anatase Nanofibers Decorated with Noble Metal Nanoparticles for Photocatalytic Production of Hydrogen. ACS Nano 2010, 5, 5025-5030. [CrossRef]

60. Wu, M.-C.; Tóth, G.; Sápi, A.; Leoni, A.R.; Kónya, Z.; Kukovecz, Á.; Su, W.-F.; Kordás, K. Synthesis and photocatalytic performance of titanium dioxide nanofibers and fabrication of flexible composite films fromnanofibers. J. Nanosci. Nanotech. 2012, 12, 1421-1424. [CrossRef]

61. Kordás, K.; Mohl, M.; Kónya, Z.; Kukovecz, Á. Layered Titanate Nanostructures: Perspectives and for Industrial Exploitation. Transl. Mater. Res. 2015, 2, 015003. [CrossRef]

62. Hoang, S.; Lu, X.; Tang, W.; Wang, S.; Du, S.; Nam, C.-Y.; Ding, Y.; Vinluan, R.D.; Zheng, J.; Gao, P.-X. High Performance Diesel Oxidation Catalysts Using Ultra-Low Pt Loading on Titania Nanowire Array Integrated Cordierite Honeycombs. Catal. Today 2019, 320, 2-10. [CrossRef]

63. Lu, X.; Tang, W.; Du, S.; Wen, L.; Weng, J.; Ding, Y.; Willis, W.S.; Suib, S.L.; Gao, P.X. Ion-Exchange Loading Promoted Stability of Platinum Catalysts Supported on Layered Protonated Titania-Deived Nanoarrays. ACS Appl. Mater. Interfaces 2019, 11, 21515-21525. [CrossRef]

64. Kolen'ko, Y.V.; Kovnir, K.A.; Gavrilov, A.I.; Garshev, A.V.; Frantti, J.; Lebedev, O.I.; Churagulov, B.R.; Van Tendeloo, G.; Yoshimura, M. Hydrothermal Synthesis and Characterization of Nanorods of Various Titanates and Titanium Dioxide. J. Phys. Chem. B 2006, 110, 4030-4038. [CrossRef] 
65. Ma, R.; Fukuda, K.; Sasaki, T.; Osada, M.; Bando, Y. Structural Features of Titanate Nanotubes/Nanobelts Revealed by Raman, X-ray Absorption Fine Structure and Electron Diffraction Characterizations. J. Phys. Chem. B 2005, 109, 6210-6214. [CrossRef] [PubMed]

66. Ohsaka, T.; Izumi, F.; Fujiki, Y. Raman spectrum of anatase, $\mathrm{TiO}_{2}$. J. Raman Spectrosc. 1978, 7, $321-324$. [CrossRef]

67. Du, Y.L.; Deng, Y.; Zhang, M.S. Variable-temperature Raman scattering study on anatase titanium dioxide nanocrystals. J. Phys. Chem. Solids 2006, 67, 2405-2408. [CrossRef]

68. Scepanovic, M.J.; Grujic-Brojcin, M.; Dohcevic-Mitrovic, Z.D.; Popovic, Z.V. Characterization of Anatase $\mathrm{TiO}_{2}$ Nanopowder by Variable-Temperature Raman Spectroscopy. Sci. Sinter. 2009, 41, 67-73. [CrossRef]

69. Wang, G.; Liu, Z.Y.; Wu, J.N.; Lu, Q. Preparation and electrochemical capacitance behaviour of $\mathrm{TiO}_{2}-\mathrm{B}$ nanotubes for hybrid supercapacitor. Mater. Lett. 2012, 71, 120-122. [CrossRef]

70. Pótári, G.; Madarász, D.; Nagy, L.; László, B.; Sápi, A.; Oszkó, A.; Kukovecz, A.; Erdőhelyi, A.; Kónya, Z.; Kiss, J. Rh-induced Support Transformation Phenomena in Titanate Nanowire and Nanotube Catalysts. Langmuir 2013, 29, 3061-3072. [CrossRef]

71. Poirier, G.E.; Hance, B.K.; White, J.M. Scanning tunneling microscopic and Auger electron spectroscopic characterization of a model catalyst: Rhodium on titania(001). J. Phys. Chem. 1993, 97, 5965-5972. [CrossRef]

72. Berkó, A.; Ménesi, G.; Solymosi, F. STM study of rhodium deposition on the $\mathrm{TiO}_{2}(110)-(1 \times 2)$ surface. Surf. Sci. 1997, 372, 202-210. [CrossRef]

73. Óvári, L.; Kiss, J. Growth of Rh nanoclusters on $\mathrm{TiO}_{2}(110)$ : XPS and LEIS studies. Appl. Surf. Sci. 2006, 252, 8624-8629. [CrossRef]

74. Evans, J.; Hayden, B.E.; Newton, M.A. A comparison of the chemistry of RhI(acac)(CO) $)_{2}$ and $\mathrm{RhI}(\mathrm{CO})_{2} \mathrm{Cl}$ adsorbed on $\mathrm{TiO}_{2}$ [110]: Development of particulate Rh and oxidative disruption by CO. Surf. Sci. 2000, 462, 169-180. [CrossRef]

75. Khosravian, H.; Liang, Z.; Uhl, A.; Trenary, M.; Meyer, R. Controlled Synthesis of Rh Nanoparticles on $\mathrm{TiO}_{2}(110)$ via $\mathrm{Rh}(\mathrm{CO})_{2}$ (acac). J. Phys. Chem. C 2012, 116, 11987-11993. [CrossRef]

76. Berkó, A.; Ménesi, G.; Solymosi, F. Scanning tunneling microscopy study of the CO-induced structural changes of Rh crystallites supported by $\mathrm{TiO}_{2}(110)$. J. Phys. Chem. 1996, 100, 17732-17734. [CrossRef]

77. Solymosi, F.; Pásztor, M. An infrared study of CO chemisorption on the topology of supported rhodium. J. Phys. Chem. 1985, 89, 4789-4793. [CrossRef]

78. Prime, M. Infrared study of CO chemisorption on zeolite and alumina supported rhodium. J. Chem. Soc. Faraday Trans. 1 Phys. Chem. Condens. Phases 1978, 74, 2570-2580.

79. Rice, C.A.; Worley, S.D.; Curtis, C.W.; Guin, J.A.; Tarrer, A.R. The oxidation state of dispersed $\mathrm{Rh}$ on $\mathrm{Al}_{2} \mathrm{O}_{3}$. J. Chem. Phys. 1981, 74, 6487-6497. [CrossRef]

80. Varga, E.; Pusztai, P.; Oszkó, A.; Baán, K.; Erdőhelyi, A.; Kónya, Z.; Kiss, J. Stability and Temperature-induced Agglomerization of Rh Nanoparticles Supported by $\mathrm{CeO}_{2}$. Langmuir 2016, 32, 2761-2770. [CrossRef]

81. Kibis, L.S.; Svintsitskiy, D.A.; Derevyannikova, E.A.; Kardash, T.Y.; Slavinskaya, E.M.; Svetlichnyi, V.A.; Boronin, A.I. From high dispersed Rh3+ to nanoclusters and nanoparticles: Probing the low-temperature $\mathrm{NO}+\mathrm{CO}$ activity of Rh-doped CeO2 catalysts. Appl. Surf. Sci. 2019, 493, 1055-1066. [CrossRef]

82. Idriss, H.; Llorca, J. Low Temperature Infrared Study of Carbon Monoxide Adsorption on $\mathrm{Rh} / \mathrm{CeO}_{2}$. Catalysts 2019, 9, 598. [CrossRef]

83. Henry, C.R. Surface studies of supported model catalysts. Surf. Sci. Rep. 1988, 31, 231-233. [CrossRef]

84. Solymosi, F. Importance of the electric properties of supports in the carrier effect. Catal. Rev. 1967, 1, $233-255$. [CrossRef]

85. Sasahara, A.; Pang, C.L.; Onishi, H. Probe Microscope Observation of Platinum Atoms Deposited on the TiO2(110)- $(1 \times 1)$ Surface. J. Phys. Chem. B 2006, 110, 13453-13457. [CrossRef] [PubMed]

86. Sasahara, A.; Pang, C.L.; Onishi, H. Local Work Function of Pt Clusters Vacuum-Deposited on a $\mathrm{TiO}_{2} \mathrm{Surface}$ J. Phys. Chem. B 2006, 110, 17584-17588. [CrossRef] [PubMed]

87. Kiss, J.; Németh, R.; Koós, Á.; Raskó, J. Characterization of Au-Rh/TiO 2 Bimetallic Nanocatalysts by CO and $\mathrm{CH}_{3} \mathrm{CN}$ Adsorption: XPS, TEM and FTIR Measurements. J. Nanosci. Nanotech. 2009, 9, 3828-3836. [CrossRef]

88. Oszkó, A.; Pótári, G.; Erdőhelyi, A.; Kukovecz, Á.; Kónya, Z.; Kiricsi, I.; Kiss, J. Structure of Au-Rh bimetallic system formed on titanate nanowires and nanotubes. Vacuum 2011, 85, 1114-1119. [CrossRef] 
89. Kiss, J.; Óvári, L.; Oszkó, A.; Pótári, G.; Tóth, M.; Baán, K.; Erdőhelyi, A. Structure and reactivity of $\mathrm{Au}-\mathrm{Rh}$ bimetallic clusters on titanate nanowires, nanotubes and $\mathrm{TiO}_{2}(110)$. Catal. Today 2012, 181, 163-170. [CrossRef]

90. Tóth, M.; Kiss, J.; Oszkó, A.; Pótári, G.; László, B.; Erdőhelyi, A. Hydrogenation of Carbon Dioxide on Rh, $\mathrm{Au}$ and $\mathrm{Au}-\mathrm{Rh}$ Bimetallic Clusters Supported on Titanate Nanotubes, Nanowires and $\mathrm{TiO}_{2}$. Top. Catal. 2012, 55, 747-756. [CrossRef]

91. Solymosi, F.; Bánsági, T.; Erdőhelyi, A. Infrared study of the surface interaction between $\mathrm{H}_{2}$ and $\mathrm{CO}_{2}$ over rhodium on various supports. J. Chem. Soc. Faraday Trans. 1981, 77, 2645-2657. [CrossRef]

92. Inoune, T.; Iizuka, T.; Tanabe, K. Hydrogenation of carbon dioxide and carbon monoxide over supported rhodium catalysts under 10 bar pressure. Appl. Catal. 1989, 46,1-9. [CrossRef]

93. Novák, E.; Fodor, K.; Szailer, T.; Oszkó, A.; Erdőhelyi, A. $\mathrm{CO}_{2}$ Hydrogenation on $\mathrm{Rh} / \mathrm{TiO}{ }_{2}$ Previously Reduced at Different Temperatures. Top. Catal. 2002, 20, 107-117. [CrossRef]

94. Ruiz-Gracia, J.R.; Fierro-Gonzales, J.C.; Handy, B.E.; Hinojosa-Reyes, L.; De Haro Del Rio, D.A.; Lucio-Ortiz, C.J.; Valle-Cervantes, S.; Flores-Escamilla, G.A. An In Situ Infrared Study of $\mathrm{CO}_{2} \mathrm{Hydrogenation}$ to formic Acid by Using Rhodium Supported on Titanate Nanotubes as Catalysts. ChemistrySelect 2019, 4, 4206-4216. [CrossRef]

95. Óvári, L.; Bugyi, L.; Majzik, Zs.; Berko, A.; Kiss, J. Surface Structure and Composition of Au-Rh Bimetallic nanoclusters on $\mathrm{TiO}_{2}$ (110): A LEIS and STM study. J. Phys. Chem. C 2008, 112, 18011-18016. [CrossRef]

96. Óvári, L.; Berkó, A.; Balázs, N.; Majzik, Zs.; Kiss, J. Formation of Rh-Au Core-Shell Nanoparticles on $\mathrm{TiO}_{2}$ (110) Surface Studied by STM and LEIS. Langmuir 2010, 26, 2167-2175. [CrossRef] [PubMed]

97. Palotás, K.; Óvári, L.; Vári, G.; Gubó, R.; Farkas, A.P.; Kiss, J.; Berkó, A.; Kónya, Z. Au-Rh surface structures on Rh(111): DFT-insights to the formation of an ordered surface alloy. J. Phys. Chem. C 2018, 122, 22435-22447. [CrossRef]

98. Tenny, S.A.; Ratliff, J.S.; Roberts, C.C.; He, W.; Ammal, S.C.; Heyden, A.; Chen, D.A. Adsorbate-Induced Changes in the Surface Composition of Bimetallic Clusters: Pt-Au on $\mathrm{TiO}_{2}(110)$. J. Phys. Chem. C 2010, 114, 21652-21663. [CrossRef]

99. Gao, F.; Wang, Y.; Goodman, D.W. Reaction Kinetics and Polarization-Modulation Infrared Reflection Absorption Spectroscopy (PM-IRAS) Investigation of CO Oxidation over Supported Pd-Au Alloy Catalysts. J. Phys. Chem. C 2010, 114, 4036-4043. [CrossRef]

100. Ozturk, O.; Park., J.B.; Ma, S.; Ratliff, J.S.; Zhou, J.; Mullins, D.R.; Chen, D.A. Probing the interactions of Pt, $\mathrm{Rh}$ and bimetallic Pt-Rh clusters with the $\mathrm{TiO}_{2}(110)$ support. Surf. Sci. 2007, 601, 3099-3113. [CrossRef]

101. Ferrando, R.; Jellinek, J.; Johnson, R.I. Nanoalloys: From Theory to Applications of Alloy Clusters and Nanoparticles. Chem. Rev. 2008, 108, 845-910. [CrossRef]

102. Kecskés, T.; Raskó, J.; Kiss, J. FTIR and mass spectrometric study of HCOOH interaction with TiO2 supported Rh and Au catalysts. Appl. Catal. A: General 2004, 268, 9-16.

103. Wang, X.; Hong, Y.; Shi, H.; Szanyi, J. Kitetic modelling and transient DRIFTS-MS studies of $\mathrm{CO}_{2}$ methanation over $\mathrm{Ru} / \mathrm{Al}_{2} \mathrm{O}_{3}$ catalysts. J. Catal. 2016, 343, 185-195. [CrossRef]

104. Wang, X.; Shi, H.; Kwak, J.H.; Szanyi, J. Mechanism of $\mathrm{CO}_{2}$ hydrogenation on $\mathrm{Pt} / \mathrm{Al}_{2} \mathrm{O}_{3}$ Catalysts. J. ACS Catal. 2015, 5, 6337-6349. [CrossRef]

105. Kecskés, T.; Raskó, J.; Kiss, J. FTIR and mass spectrometric studies on the interaction of formaldehyde with $\mathrm{TiO}_{2}$ supported Pt and Au catalysts. Appl. Catal. A Gen. 2004, 273, 55-62. [CrossRef]

106. Sápi, A.; Halasi, G.; Kiss, J.; Dobó, D.G.; Juhász, K.L.; Kolcsár, V.J.; Ferencz, Z.; Vári, G.; Matolin, V.; Erdőhelyi, A.; et al. In Situ DRIFTS and NAP-XPS Exploration of the Complexity of $\mathrm{CO}_{2}$ Hydrogenation over Size-Controlled Pt Nanoparticles Supported on Mesoporous NiO. J. Phys. Chem. C 2018, 122, 5553-5565. [CrossRef]

107. Wang, X.; Shi, H.; Szanyi, J. Controlling selectives in $\mathrm{CO}_{2}$ reduction through mechanistic understanding. Nat. Commun. 2017, 8, 513-519. [CrossRef] [PubMed]

108. Baltrusaitis, J.; Schuttlefield, J.; Zeitler, E.; Grassian, V.H. Carbon dioxide adsorption on oxide nanoparticle surfaces. Chem. Eng. J. 2011, 170, 471-481. [CrossRef]

109. Raskó, J.; Kecskés, T.; Kiss, J. Adsorption and reaction of formaldehyde on $\mathrm{TiO}_{2}$-supported Rh catalysts studied by FTIR and mass spectrometry. J. Catal. 2004, 226, 183-191. [CrossRef]

110. Simanouchi, T. Tables of Molecular Vibrational Frequeces Consolidated, Volume 1; National Bureau of Standards: Washington, DC, USA, 1972. 
111. Ichikawa, M.; Fukushima, T. Infrared studies of metal additive effects on carbon monoxide chemisorption modes on silicon dioxide-supported rhodium-manganese-titanium and iron catalysts. J. Phys. Chem. 1985, 89, 1564-1567. [CrossRef]

112. Stevenson, S.A.; Lisistsyn, A.; Knözinger, H. Adsorption of carbon monoxide on manganese-promoted rhodium/silica catalysts as studied by infrared spectroscopy. J. Phys. Chem. 1990, 94, 1576-1581. [CrossRef]

113. Chuang, S.S.C.; Stevens, R.W.; Khatri, R. Mechanism of C2+ oxygenate synthesis on Rh catalysts. Top. Catal. 2005, 32, 225-232. [CrossRef]

114. Sápi, A.; Kashaboina, U.; Baán, K.; Perez Gomez, J.; Szenti, I.; Halasi, Gy.; Kiss, J.; Nagy, B.; Varga, T.; Kukovecz, Á.; Kónya, Z. Synergetic of Pt nanoparticles and H-ZSM-5 zeolites for efficient $\mathrm{CO}_{2}$ activation: Role of interfacial sites in high activity. Front. Mate. 2019, 6, 127. [CrossRef]

115. Kattel, S.; Yan, B.; Chen, J.G.; Liu, P. $\mathrm{CO}_{2}$ hydrogenation on $\mathrm{Pt}, \mathrm{Pt} / \mathrm{SiO}_{2}$ and $\mathrm{Pt} / \mathrm{TiO}_{2}$ : $\mathrm{Importance}$ of synergy between Pt and oxide support. J. Catal. 2016, 343, 115-120. [CrossRef]

116. Fisher, A.I.; Bell, A.T. A Comparative Study of $\mathrm{CO}$ and $\mathrm{CO}_{2}$ Hydrogenation over $\mathrm{Rh} / \mathrm{SiO}_{2}$. J. Catal. 1996, 162, 54-65. [CrossRef]

117. Yu, K.P.; Yu, W.Y.; Kuo, M.C.; Liou, Y.C.; Chien, S.H. Pt/titanate-nanotubes; A potential catalyst for $\mathrm{CO}_{2}$ hydrogenation. Appl. Catal. B 2008, 281, 112-118. [CrossRef]

118. Farkas, A.P.; Solymosi, F. Activation and reaction of $\mathrm{CO}_{2}$ on K-promoted $\mathrm{Au}(111)$ surface. J. Phys. Chem. C 2009, 113, 19930-19936. [CrossRef]

119. Byron, S.R.J.; Muruganandam, I.; Murthy, S.S. A review of the water gas shift reaction kinetics. Int. J. Chem. React. Eng. 2010, 8. [CrossRef]

120. Gokhale, A.A.; Dumesic, J.A.; Mavrikakis, M.M. On the mechanism of low temperature water gas shift reaction on copper. J. Am. Chem. Soc. 2008, 130, 1402-1414. [CrossRef]

121. Soria, M.A.; Perez, P.; Carabineiro, S.A.C.; Hodar, F.J.M.; Mendes, A.; Madeira, L.M. Effect of the preparation method on the catalytic activity and stability of $\mathrm{Au} / \mathrm{Fe}_{2} \mathrm{O}_{3}$ catalysts in the low-temperature water-gas shift reaction. Appl.Catal. A Gen. 2014, 470, 45-55. [CrossRef]

122. Lloyd, L.; Ridler, D.E.; Twigg, M.V. The Water-Gas Shift Reaction. In Catalyst Handbook, 2nd ed.; Frome, Chapter; Twigg, M.V., Ed.; Manson Publishing Ltd.: London, UK, 1996; Volume 6, p. 283.

123. Ladebeck, J.R.; Wagner, J.P. Catalyst development for water-gas shift. In Handbook of Fuel Cell-Fundamentals, Technology and Applications; Wolf, V., Arnold, L., Hubert, A.G., Eds.; John Wiley \& Sons: Hoboken, NJ, USA, 2003; Volume 3, pp. 190-201.

124. Li, Y.; Fu, Q.; Flytzani-Stephanopoulos, M. Low-temperature water-gas shift reaction over Cu- and Ni-loaded cerium oxide catalysts. Appl. Catal. B Envir. 2000, 27, 179-191. [CrossRef]

125. Li, J.; Yoon, H.; Oh, H.T.; Washman, E.D. $\mathrm{SrCe}_{0.7} \mathrm{Zr}_{0.2} \mathrm{Eu}_{0.1} \mathrm{O}_{3}$-based hydrogen transport water gas shift reactor. Int. J. Hydrog. Energy 2012, 37, 16006-16012. [CrossRef]

126. Grabow, L.C.; Gokhale, A.A.; Evans, S.T.; Dumesic, A.; Mavrikakis, M. Mechanism of the water gas shift reaction on Pt: First Principles, Experiments, and microkinetic modeling. J. Phys. Chem. C 2008, 112, 4608-4617. [CrossRef]

127. Ovesen, C.V.; Clausen, B.S.; Hammershoi, B.S.; Steffensen, G.; Askgaard, T.; Chorkendorff, I.; Norskov, J.K.; Rasmussen, P.B.; Stolze, P.; Taylor, P.A. Microkinetic analysis of the water gas reaction under industrial conditions. J. Catal. 1996, 158, 170-180. [CrossRef]

128. Kölbel, H.; Bhasttocharga, K.K. Synthese hochschmelzender Paraffine an Ruthenium-Kontakten. Just. Leibigs Ann. Chem. 1958, 618, 67-71. [CrossRef]

129. Niwa, M.; Lunsford, L.H. The catalityc reactions of $\mathrm{CO}$ and $\mathrm{H}_{2} \mathrm{O}$ over supported rhodium. J. Catal. 1982, 75, 302-313. [CrossRef]

130. Solymosi, F.; Erdőhelyi, A.; Tombácz, I. Methane synthesis in the $\mathrm{H}_{2} \mathrm{O}+\mathrm{CO}$ reaction over titania supported Rh and Rh-Pt catalysts. Appl. Catal. 1985, 14, 65-67. [CrossRef]

131. Diagne, C.; Idriss, H.; Kiennemann, A. Hydrogen production by ethanol reforming over $\mathrm{Rh} / \mathrm{CeO}_{2}-\mathrm{ZrO}_{2}$ catalysts. Catal. Commun. 2002, 3, 565-571. [CrossRef]

132. Aupretre, F.; Descorme, C.; Duprez, D. Bio-ethanol catalytic steam reforming over supported metal catalysts. Catal. Commun. 2002, 3, 263-267. [CrossRef]

133. Liguras, D.K.; Kondarides, D.J.; Verykios, X.E. Production of hydrogen for fuel cells by steam-reforming of ethanol over supported noble metal catalysts. Appl. Catal. B Environ. 2003, 43, 345-354. [CrossRef] 
134. Raskó, J.; Hancz, A.; Erdőhelyi, A. Surface species and gas phase products in steam reforming of ethanol on $\mathrm{TiO}_{2}$ and $\mathrm{Rh} / \mathrm{TiO}_{2}$. Appl. Catal. A Gen. 2004, 269, 13-25. [CrossRef]

135. Erdőhelyi, A.; Raskó, J.; Kecskés, T.; Tóth, M.; Dömök, M.; Baán, K. Hydrogen formation in ethanol steam reforming on supported noblemetal catalysts. Catal. Today 2006, 116, 367-376. [CrossRef]

136. Ferencz, Zs.; Erdőhelyi, A.; Baán, K.; Oszkó, A.; Óvári, L.; Kónya, Z.; Papp, C.; Steinrück, H.-P.; Kiss, J. Effects of Support and Rh Additive on Co-Based Catalysts in the Ethanol Steam Reforming Reaction. ACS Catal. 2014, 4, 1205-1218. [CrossRef]

137. Idriss, H.; Seebauer, E.G. Reactions of ethanol over metal oxide. J. Mol. Catal. A 2000, 152, 201-212. [CrossRef]

138. Nadeem, M.A.; Murdoch, M.; Waterhouse, G.I.N.; Metson, J.B.; Keane, M.A.; Llorca, J.; Idriss, H. Photoreaction of ethanol on $\mathrm{Au} / \mathrm{TiO}_{2}$ anatase: Comparing the micro to nanoparticlesize activities of the support for hydrogen production. J. Photochem. Photobiol. A Chem. 2010, 216, 250-255. [CrossRef]

139. Papageorgopoulos, D.C.; Ge, Q.; King, D.A. Synchronous Thermal Desorption and Decomposition of Ethanol on Rh\{111\}. J. Phys. Chem. 1995, 99, 17645-17649. [CrossRef]

140. Houtman, C.J.; Barteau, M.A. Divergent Pathways of Acetaldehyde and Ethanol Decarbonylation on the Rh(111) Surface. J. Catal. 1991, 130, 528-546. [CrossRef]

141. de Lima, S.M.; da Cruz, I.O.; Jacobs, G.; Davis, B.H.; Mattos, L.V.; Noronha, F.B. Steam reforming, partal oxidation, and oxidative steam reforming of ethanol over $\mathrm{Pt} / \mathrm{CeZ} \mathrm{rO}_{2}$ catalyst. J. Catal. 2008, 257, 356-368. [CrossRef]

142. Tóth, M.; Varga, E.; Baán, K.; Oszkó, A.; Kiss, J.; Erdőhelyi, A. Partial oxidation of ethanol on supported Rh catalysts: Effect of the oxide support. J. Mol. Catal. A Chem. 2016, 411, 377-387. [CrossRef]

143. Solymosi, F.; Erdőhelyi, A.; Kocsis, M. Surface interaction between $\mathrm{H}_{2}$ and $\mathrm{CO}_{2}$ on $\mathrm{Rh} / \mathrm{Al}_{2} \mathrm{O}_{3}$ studied by adsorption and infrared spectroscopic measurements. J. Catal. 1980, 65, 428-436. [CrossRef]

144. Di Cosimo, J.I.; Diez, V.K.; Xu, M.; Iglesia, E.; Apesteguia, C.R. Structure and Surface and Catalytic Properties of Mg-Al Basic Oxides. J. Catal. 1998, 178, 499-510. [CrossRef]

(C) 2020 by the authors. Licensee MDPI, Basel, Switzerland. This article is an open access article distributed under the terms and conditions of the Creative Commons Attribution (CC BY) license (http://creativecommons.org/licenses/by/4.0/). 